ISSN 0081-7147

e-ISSN 2451-1331

\title{
Cyfrowe edycje map dawnych: perspektywy i ograniczenia na przykładzie mapy Gaula/Raczyńskiego (1807-1812)*
}

Zarys treści: Artykuł ma dwa zasadnicze cele. Pierwszym jest przedstawienie dotychczasowego dorobku teoretycznego w zakresie edytorstwa źródeł kartograficznych, a drugim omówienie i prezentacja propozycji modelu cyfrowych edycji dawnych map na przykładzie mapy Gaula/Raczyńskiego z początku XIX w. Najistotniejsze pytania, na które autor poszukuje odpowiedzi, dotyczą m.in. relacji między edycją mapy a edycją tekstu, różnic między naukowymi a popularnonaukowymi edycjami map, roli narzędzi cyfrowych w edytorstwie, różnic i zależności pomiędzy edycją mapy a kartografią i mapą historyczną, a także - na zakończenie - problemów stabilności i utrzymania cyfrowych projektów.

Abstract: The article has two main goals. The first is to present the theoretical foundations in the field of cartographic sources editing, and the second is to discuss and present proposals for the model digital edition of old maps on the example of the Gaul/Raczyński map from the early $19^{\text {th }}$ century. The most important questions concern relations between editing cartographic and written sources, differences between scientific and popular map editions, the role of digital tools in editing, differences and dependencies between map editing, cartography and historical map, and - finally - problems of sustainability of digital projects.

Słowa kluczowe: edycje map, mapa topograficzna, kartografia historyczna, historia kartografii, Systemy Informacji Geograficznej, GIS

Keywords: map editions, topographic map, historical cartography, history of cartography, Geographic Information Systems, GIS

\section{Wprowadzenie}

Naukowe edytorstwo źródeł historycznych sięga XIX w., a u jego podstaw leżała tzw. metoda filologiczna Karla Lachmanna, zakładająca poszukiwanie archetypu źródła pisanego poprzez opracowanie jego drzewa genealogicznego (stemma codicum), a sam proces edycji polegał na ustaleniu tekstu źródła na podstawie zachowanych egzemplarzy (recensio) i poprawienie go, w celu przybliżenia do przekazu autorskiego (emendatio) $)^{1}$. Podstawowym założeniem edytorstwa pozostawało i - jak się wydaje - wciąż pozostaje wydanie tekstu źródłowego poprzez jego przepisanie i wydrukowanie ${ }^{2}$. W gutenbergowskim

* Publikacja powstała w ramach projektu Cyfrowe edycje map dawnych: perspektywy i ograniczenia na przykładzie „Mapy geograficzno-wojskowej i statystycznej Wielkopolski” (1807-1812), finansowanego przez Narodowe Centrum Nauki (nr 2015/17/N/HS3/01267). Edycja wraz z materiałami towarzyszącymi oraz wstępną wersją niniejszego tekstu dostępne są na stronie: <http://atlasfontium.pl/index.php?article=gaul> [dostęp: 15.04.2020].

1 J. Tandecki, K. Kopiński, Edytorstwo źródet historycznych, Warszawa 2014, s. 17.

2 D. Schloen, S. Schloen, Beyond Gutenberg. Transcending the Document Paradigm in Digital Humanities, „Digital Humanities Quarterly”, 8, 2014, nr 4, <http://www.digitalhumanities.org/dhq/vol/8/4/000196/000196.html> [dostęp: 20.04.2020]. 
paradygmacie druku użytkownik ma dostęp do źródła za pośrednictwem jego odczytu, który powinien być możliwie zbliżony do oryginału, a interpretacje ograniczane do minimum ${ }^{3}$. Sposoby poprawnego przepisania, ustalenia i krytyki przekazu źródłowego stały się kanwą instrukcji wydawniczych regulujących kwestie uproszczeń, uzupełnień, korygowania ortografii czy opracowywania wstępów i nagłówków. W końcu XX w. pojawiły się narzędzia cyfrowe, które pozwoliły na wydawanie tzw. edycji faksymilowych, dających czytelnikowi możliwość zajrzenia do źródła bez pośredniego przekazu w postaci odczytanego tekstu ${ }^{4}$. Tzw. paradygmat cyfrowy zmienia w sposób istotny pryncypia edytorstwa przede wszystkim dzięki silniejszemu zaakcentowaniu edycji jako procesu ciągłego i otwartego ${ }^{5}$. Cyfrowe edycje, którym należy przeciwstawić edycje ucyfrowione, np. książki udostępniane w formacie *.pdf, cechują się przede wszystkim otwartością, modułowością, algorytmizacją oraz łączą różne rodzaje mediów (skan, tekst) poprzez hiperlinki, a ich naturalnym środowiskiem jest Internet ${ }^{6}$.

Zasady edytorstwa źródeł dotyczą w większości źródeł pisanych, ale nie można pomijać tu źródeł kartograficznych, ważnych nie tylko dla badań historyczno-geograficznych. Opracowanie zasad ich udostępnienia jest istotne $\mathrm{z}$ dwóch względów. Po pierwsze, zapewniają zasób informacji niedostępny w źródłach pisanych, pokazują stopień opanowywania i opisania przestrzeni oraz dokumentują rozwój nauki i techniki. Po drugie, mapy są interesujące nie tylko dla profesjonalnych badaczy, ale także dla genealogów czy regionalistów. Autor niniejszego artykułu ma dwa zasadnicze cele. Pierwszym jest przedstawienie dotychczasowego dorobku teoretycznego w zakresie edytorstwa źródeł kartograficznych, a drugim omówienie i prezentacja propozycji modelu cyfrowych edycji dawnych map na przykładzie mapy Gaula/Raczyńskiego z początku XIX w. Najistotniejsze pytania, na które poszukuje odpowiedzi, dotyczą m.in. relacji między edycją mapy a edycją tekstu, różnic między naukowymi (rzadkimi!) a popularnonaukowymi (dominującymi) edycjami map, roli narzędzi cyfrowych w edytorstwie, różnic i zależności pomiędzy edycją mapy a kartografią i mapą historyczną, a także - na zakończenie problemów stabilności i utrzymania cyfrowych projektów.

\section{Edytorstwo źródel kartograficznych}

Dotychczasowe próby zdefiniowania zarówno pojęcia edytorstwa źródeł kartograficznych, jak również jego zakresu przedmiotowego należy uznać za niewystarczające. W swoim podręczniku Janusz Tandecki i Krzysztof Kopiński wspominali o edycjach map, traktując je na równi z przekazami stricte ikonograficznymi, a także błędnie uznając serię Atlasu Historycznego Polski. Mapy Szczegółowe XVI wieku za edycję źródłową7. Stephen E. Wiberley wyróżnił pięć rodzajów edycji map, które mogą znaleźć zastosowanie w kartografii historycznej: facsimile dawnej mapy, facsimile z dodatkową treścią, mapa współczesna, antydatowana mapa współczesna lub mapa historyczna opracowana na podstawie map dawnych ${ }^{8}$. Nie zdefiniował on jednak pojęcia „edycji”, a kierował się raczej zastosowaniem map w kartografii historycznej rozumianej dość szeroko za Raleigh A. Skeltonem jako „działania, za pomocą których okoliczności z czasów przeszłych zostają odtwarzane lub też wykrywane w okolicznościach dzisiejszych"9. Stąd też w jego spisie typów edycji znajdują się mapy współczesne, które mogą służyć na podkład do prezentacji zjawisk historycznych.

\footnotetext{
${ }^{3}$ M. Słoń, Sine initio et sine fine. Edycja źródła jako proces zawsze otwarty, w: Editiones sine fine, t. 1, red. K. Kopiński, W. Mrozowicz, J. Tandecki, Torun 2017, s. 132 n.

${ }^{4}$ J. Sowiński, Między oryginałem, kopia a falsyfikatem. Polskie edycje faksymilowe, Kraków 2009.

${ }_{5}^{5}$ M. Słoń, M. Słomski, Edycje cyfrowe źródeł historycznych, w: Jak wydawać teksty dawne, red. K. Borowiec, D. Masłej, T. Mika, D. Rojszczak-Robińska, Poznań 2017, s. 65-84.

${ }^{6}$ P. Sahle, What is a Scholarly Digital Edition?, w: Digital Scholarly Editing. Theories and Practices, red. M.J. Driscoll, E. Pierazzo, Cambridge 2016, s. 19-41.

7 J. Tandecki, K. Kopiński, Edytorstwo źródeł historycznych, s. 200-203.

${ }^{2}$ S.E. Wiberley, Editing Maps. A Method for Historical Cartography, „Journal of Interdisciplinary History”, 10, 1980, nr 3 , s. 499.

9 R.A. Skelton, Maps. A Historical Survey of Their Study and Collecting, Chicago 1972, s. 62 (thum. T.P.).
} 
Chociaż S.E. Wiberley nie definiuje wprost pojęcia „edycji mapy”, to można domniemywać, że w jego konceptualizacji jest to opracowanie uwspółcześnionej wersji mapy dawnej. Wymienia on katalog zabiegów edytorskich, takich jak: uwspółcześnienie symbolizacji, wydatowanie mapy, korygowanie błędów (tak nazewniczych, jak i geometrycznych) oraz opracowanie komentarza edytorskiego służącego za dokumentację procesu ${ }^{10}$. Mapa, która może zostać w ten sposób wydana, powinna spełniać wymóg dostatecznej dokładności, dzięki czemu można ją przerysować, uwspółcześnić i wykorzystać jako podkład do prezentacji zjawisk historycznych. Trudno jednak w pełni zgodzić się z tym stwierdzeniem. Po pierwsze dlatego, że jeżeli przyjmujemy definicję edycji jako „krytycznej reprezentacji dokumentu historycznego" 11 , to reprezentacja nie musi zakładać oddania kompletnego zakresu treści dokumentu (w tym przypadku mapy), np. poprzez jego pełen odczyt, ale także poszczególnych warstw informacyjnych, np. nazw na mapie. W takim wypadku częścią edycji byłyby te elementy treści, które można zlokalizować i nanieść na mapę współczesną, np. informacje o miejscowościach (nazwa, rodzaj) czy innych antropogenicznych obiektach (np. lokalizacja brodów w Wielkopolsce w świetle mapy Godfryda Freudenhamera ${ }^{12}$ ). Po drugie, odzwierciedlenie w edycji relacji przestrzennych, o których wiadomo, że obarczone są błędami, jest jednym z elementów badania dokładności map i oceny poprawności położenia obiektów, a bez tych informacji trudno ocenić wiarygodność przekazu kartograficznego.

Na zagadnienie edycji dawnych map zwracano uwagę także w serii Atlasu Historycznego Miast Polskich, przy czym dopiero w latach 90 . XX w. pojawiła się potrzeba reprodukowania większej liczby dawnych map ${ }^{13}$. Dawne plany miast są elementem serii w dwojaki sposób. Po pierwsze, jako facsimile, które mają pokazać mapy jako źródła historyczne do rekonstrukcji topografii oraz - dzięki umieszczeniu w Atlasie wielu różnych dawnych planów - także jako serie ukazujące zmiany przestrzenne. Po drugie, pełnią rolę podkładu, na który nanoszona jest treść tematyczna, np. przestrzenny rozwój miasta czy ważniejsze obiekty - także te, które poświadczone były wcześniej niż reprodukowany pod$\mathrm{kład}^{14}$. Dotyczy to głównie planów katastralnych, do niedawna prezentowanych jako facsimile, a od pewnego czasu traktowanych jako źródło danych do opracowania cyfrowego podkładu z wykorzystaniem narzędzi GIS ${ }^{15}$. Przy tej okazji należy też wspomnieć o edycjach wybranych planów Warszawy wydawanych staraniem Muzeum Warszawy w serii Plany Warszawy. Dotychczas wydano pięć planów: La Rouge'a z 1768 r. ${ }^{16}$, Korpusu Inżynierów z 1825 r. ${ }^{17}$, Lindleya z 1912 r. ${ }^{18}$, Książnicy-Atlas z 1939 r. ${ }^{19}$ oraz plan z 1955 r. $^{20}$

${ }^{10}$ S.E. Wiberley, Editing Maps, s. 500 n.

${ }^{11}$ P. Sahle, What is a Scholarly Digital Edition?, s. 19-41 (tłum. T.P.).

12 G. Kwiatkowska-Gadomska, S. Pietkiewicz, Mapa „Palatinatus Posnaniensis” Jerzego Freudenhamera, „Studia i Materiały z Dziejów Nauki Polskiej”, Seria C, 24, 1980; H. Rutkowski, Godfryd Freudenhamer, w: Polski wkład w przyrodoznawstwo i technikę. Słownik polskich i zwiazanych z Polska odkrywców, wynalazców oraz pionierów nauk matematyczno-przyrodniczych i techniki, t. 6, red. B. Orłowski, Warszawa 2015, s. 422 n.; T. Panecki, Źródła kartograficzne, w: Wielkopolska $w$ drugiej połowie XVI wieku, cz. 2: Komentarz, indeksy, red. M. Słoń, K. Chłapowski, Atlas Historyczny Polski. Mapy Szczegółowe XVI wieku, t. 4, Warszawa 2017, s. 29-37.

${ }_{13}$ R. Czaja, Historical Atlas of Polish Towns - Between Source Edition and the Cartographic Presentation of Research on the History of Towns, „Studia Geohistorica”, 6, 2018, s. 84.

${ }^{14}$ Tenże, Zu editorischen Probleme der Katasterkarte im Historischen Atlas Polnischer Städte, w: Städteatlanten. Vier Jahrzehnte Atlasarbeit in Europa, red. W. Ehbrecht, Städteforschungen, t. 80, Köln-Weimar-Wien 2013, s. 141-151.

15 Tenże, Historical Atlas of Polish Towns, s. 87.

${ }^{16}$ G.L. Le Rouge, Plan Warszawy: 1768: dedykowany Stanisławowi Augustowi, Królowi Polskiemu Wielkiemu Księciu Litewskiemu, przez jego pokornego i uniżonego stuge Le Rouge'a, wyd. K. Wagner, P.E. Weszpiński, W. Pietrusiewicz, Warszawa 2017.

${ }^{17}$ Korpus Inżynierów Wojskowych, Plan Miasta Stołecznego Warszawy: Wymierzony przez Officerów Korpusu Inżynierów w latach 1818 i 1819 i litografowany przez tychże roku 1822, wyd. P.E. Weszpiński, H. Bartoszewicz, Warszawa 2018.

18 W.H. Lindley, Plan niwelacyjny miasta Warszawy, wyd. R. Żelichowski, P.E. Weszpiński, Warszawa 2016.

${ }^{19}$ Instytut Kartograficzny imienia E. Romera, Plan miasta stołecznego Warszawy, wyd. P.E. Weszpiński, J. Trybuś, Warszawa 2017.

${ }^{20}$ Państwowe Przedsiębiorstwo Wydawnictw Kartograficznych, Plan dzielnic centralnych m. st. Warszawy, wyd. P.E. Weszpiński, A. Skalimowski, Warszawa 2018. 
Jeżeli chodzi o analogowe edycje map topograficznych, to najbardziej znanym jest obecnie projekt edycji tzw. mapy Miega, tj. austriackiego zdjęcia józefińskiego ${ }^{21}$. Program wydawniczy zaplanowano na piętnaście tomów zawierających faksymilowe edycje arkuszy mapy, jak również pełny odczyt towarzyszących im opisów wraz z tłumaczeniem na język polski. Każdy tom wydawnictwa składa się z wyczerpującego komentarza kartoznawczego, który dotyczy zarówno okoliczności powstania mapy, zakresu jej treści, wraz ze szczegółowymi opisami i rycinami stosowanych znaków topograficznych, jak również oceny jej dokładności. Edycja, mimo swojego rozmachu, nie jest pozbawiona wad. Po pierwsze, użytkownicy zwracają uwagę na dość szybkie przecieranie się reprodukowanych arkuszy na zgięciach, co może sprawić, że w ciągu kilku lat przy intensywnym wykorzystywaniu reprodukcje staną się nieczytelne. Po drugie, pełnotekstowa edycja opisów wraz z thumaczeniem jest niezwykle czasochłonna, a brak jej cyfrowej wersji, a przez to bezpośredniego odniesienia treści np. do dzisiejszych miejscowości poprzez identyfikatory (lub chociażby współrzędne geograficzne) nie spełnia wymogów współczesnej geografii historycznej. Po trzecie, autorzy edycji nie pokusili się o zarysowanie teoretycznego tła tych prac w kontekście potrzeb i ograniczeń edytorstwa źródeł kartograficznych. Mapa Miega funkcjonuje także w obiegu naukowym poprzez cyfrową edycję na portalu Mapire. The Historical Map Portal (https://mapire.eu/en/; dostęp: 23.10.2019).

Bardzo dużo miejsca w literaturze poświęca się również mapom dawnym jako źródłom danych do analiz zmian krajobrazu ${ }^{22}$. Wówczas opracowywane są zestawy danych kartograficznych, np. pokrycia terenu dla określonych momentów z przeszłości, które następnie są porównywane. Wymaga to de facto wykonania cyfrowej edycji mapy: osadzenia jej w układzie współrzędnych, opracowania przestrzennej bazy danych jej treści oraz przygotowania dokumentacji tego procesu. Tego typu prace niekiedy wprost nazywane są edycjami, jednak samo pojęcie „edycji” nie jest w nich zdefiniowane ${ }^{23}$. Swego czasu postulowano nawet opracowanie „banku danych” kartograficznych jako formy udostępniania dawnych map. Miał on zawierać najważniejsze elementy treści map, przerysowane wprost z nich i ujednolicone do jednolitej skali i odwzorowania ${ }^{24}$.

\section{Czym jest cyfrowa edycja mapy?}

Zdaniem autora, na podstawie dotychczasowych wypracowanych doświadczeń w zakresie cyfrowego przetwarzania map dawnych, jak również definicji edytorstwa można przyjąć, że edycja źródła kartograficznego powinna oznaczać krytyczne i udokumentowane udostępnienie (reprezentację) mapy i jej treści. Oznacza to, że nie wystarczy dokonać przedruku mapy w postaci facsimile, ale konieczne jest również udostępnienie jej treści, np. w formie indeksów czy - w paradygmacie cyfrowym - bazy danych. Czym jednak jest reprezentacja źródła w przypadku mapy? Źródła kartograficzne i pisane różnią się dość istotnie pod względem sposobu przekazywania informacji. O ile tekst jest (przeważnie) ciągły i ma charakter opisowy lub narracyjny, a źródło ikonograficzne operuje symbolami graficznymi i ich rozmieszczeniem w przestrzeni dwuwymiarowej, to źródło kartograficzne stanowi nie tylko połączenie tekstu i ikonografii, ale jest także pewną reprezentacją przestrzeni o określonych podstawach matematycznych (odwzorowanie, skala). W warstwie symbolicznej mamy zatem do czynienia z sygnaturami, które oddają relacje przestrzenne (geograficzne) między obiektami, natomiast w warstwie tekstowej z ich opisami, które przeważnie dotyczą miejscowości czy obiektów fizjograficznych. Wynika zatem

${ }^{21}$ W. Bukowski, A. Janeczek, Mapa józefińska (1779-1783) w przededniu edycji, „Studia Geohistorica”, 1, 2013, s. 91-112.

22 J. Wolski, Przeksztatcenia krajobrazu wiejskiego Bieszczadów Wysokich w ciagu ostatnich 150 lat, Warszawa 2007;

B. Degórska, A. Kurek, Transformacja krajobrazu wschodnich Kujaw w kontekście zmian użytkowania ziemi i osadnictwa (1770-1970), Warszawa 2015.

${ }^{23}$ D. Lafreniere, D. Rivet, Rescaling the Past through Mosaic Historical Cartography, „Journal of Maps”, 6, 2010, nr 6, 2010, s. 417-422; M. Mastronunzio, E. Dai Prà, Editing Historical Maps. Comparative Cartography Using Maps as Tools, „e-Perimetron", 11, 2016, nr 4, s. 183-195.

${ }^{24}$ E. Krzywicka-Blum, Bank danych jako forma udostępniania dawnych map, „Polski Przegląd Kartograficzny”, 20, 1988, nr 1, s. 19-21. 
dość jasno, że przy edycjach źródeł kartograficznych należy połączyć teorię obu rodzajów źródeł pisanych i ikonograficznych oraz metody geograficzne.

W klasycznie rozumianym edytorstwie źródeł pisanych mamy do czynienia z przejściem między znajdującym się $\mathrm{w}$ archiwum rękopisem dokumentu a jego krytyczną reprezentacją $\mathrm{w}$ postaci tekstu: przejścia od obrazowego zapisu do odczytu, czyli rekodowania obrazu pod postacią ciagu jednoznacznych znaków. Poszczególne etapy tego procesu powinny obejmować takie czynności jak kwerendę archiwalną i biblioteczną w celu zebrania materiału, krytykę tekstu (zewnętrzną i wewnętrzną), odczyt i kolacjonowanie tekstu źródła wraz z ustaleniem poprawnego brzmienia, filiacji czy rekonstrukcji archetypu $^{25}$. Przygotowując publikację do druku, należy opatrzyć ją wstępem źródłoznawczym i edytorskim, aparatem naukowym oraz indeksami (geograficznym, osobowym i rzeczowym) ${ }^{26}$.

$\mathrm{Na}$ tej podstawie można przedstawić pewien katalog czynności związanych z cyfrowym edytorstwem źródeł kartograficznych, którego propozycja wynika z przekształcenia tych charakterystycznych dla źródeł pisanych. Z uwagi na specyfikę map nie jest możliwe przeniesienie ich w relacji jeden do jednego.

I tak, pierwsze dwa etapy, tj. kwerenda archiwalna oraz krytyka źródła pozostają niezmienne dla obu rodzajów źródeł. Opracowując stemma codicum, trzeba mieć świadomość, że mapa dawna może być bezpośrednim efektem pomiarów terenowych ${ }^{27}$, czyli tzw. zdjęciem stolikowym, przerysem mapy wcześniejszej z niewielkimi tylko zmianami ${ }^{28}$, redukcją (generalizacją) mapy w większej skali, najczęściej zdjęć stolikowych ${ }^{29}$, albo kompilacją różnych map ${ }^{30}$. Opracowanie drzewa genealogicznego mapy jest nie tylko prawie zawsze możliwe, ale bardzo pomocne przy dalszej krytyce. Krytyka mapy jako źródła historycznego powinna zawierać zarówno opis stanu zachowania czy techniki opracowania, jak również określenie jej wiarygodności, zakresu treści, stopnia generalizacji ${ }^{31}$.

Kolejne etapy przygotowania edycji mapy obejmują jej digitalizację i opracowanie cyfrowej reprezentacji: zarówno jako obrazu (skanowanie i georeferencja), jak i treści (opracowanie struktury bazy danych i wypełnienie jej treścią).

Reprezentacja obrazu - jak zaznaczono wcześniej - to warunek konieczny edycji. Dzięki udostępnieniu zeskanowanej mapy użytkownik ma wgląd bezpośrednio do źródła, przy czym należy zaznaczyć, że skan nie jest w pełni wiernym odwzorowaniem oryginału. Nie bez znaczenia jest umieszczenie mapy w geograficznym układzie współrzędnych w programie GIS, co umożliwia nałożenie na siebie mapy dawnej i współczesnej. Ważnym etapem edycji, który dotyczy mapy jako obrazu, powinno być także jego uczytelnienie, np. poprzez rekonstrukcję bądź wzmocnienie kolorystyki.

Reprezentacja treści mapy odnosi się do jej odczytu i opracowania indeksów rzeczowych i geograficznych w formie specjalnie zaprojektowanej bazy danych ${ }^{32}$. W bazach danych przestrzennych stosuje się wektorowy model danych, którego opracowanie polega na przerysowaniu (wektoryzacji) wybranych obiektów. Wektoryzacja dotyczy np. lokalizacji i odczytu nazw miejscowości, przebiegu dróg czy zasięgu lasów. Z punktu widzenia użyteczności edycji wektoryzacja i opracowanie bazy danych jest kluczową funkcjonalnością, ponieważ baza danych to cyfrowy odpowiednik transkrypcji oraz indeksu:

25 J. Tandecki, K. Kopiński, Edytorstwo źródet historycznych, s. 127-135.

${ }^{26}$ Tamże, s. 226 n.

${ }^{27}$ Na przykład Urmesstischblätter, ale także późniejsze Messtischblätter, chociaż należy pamiętać, że w tym ostatnim przypadku źródłem opracowania mapy mogły być też inne mapy.

${ }^{28}$ Ciekawym przykładem jest „Plan miasta Kalisza” opracowany przez O. Wollego w 1878 r. na podstawie planu Politalskiego z 1785 r., a uzupełniony przez W. Rusińskiego; por. U. Sowina, T. Związek, T. Panecki, Kalisz w połowie XVI wieku, w: Wielkopolska w drugiej połowie XVI wieku, cz. 2, s. 313-332.

29 Jako przykłady można podać mapy pruskie czy austriackie z przełomu XVIII i XIX w., np. mapę Textora opracowaną na podstawie mapy von Steina; por. T. Paćko, W. Trzebiński, Wieloarkuszowe mapy topograficzne ziem polskich 1576-1870, Centralny Katalog Zbiorów Kartograficznych w Polsce, t. 5, Wrocław 1983, poz. 40.

${ }^{30} \mathrm{Na}$ przykład tzw. mapa Reymanna; por. A. Konias, Kartografia topograficzna państwa i zaboru pruskiego od II połowy XVIII wieku do połowy XX wieku, Słupsk 2010.

31 B. Szady, Dawna mapa jako źródło w badaniach geograficzno-historycznych w Polsce, Kwart. HKM, 66, 2018, nr 2, s. 134.

${ }^{32}$ T. Panecki, Koncepcja struktury bazy danych historycznych obiektów topograficznych, Warszawa 2018, mps pracy doktorskiej, Wydział Geografii i Studiów Regionalnych UW. 
geograficznego (lokalizacja obiektów) i rzeczowego (rodzaje obiektów). Może ona zawierać także odnośniki do innych zasobów danych, np. współczesnych (urzędowych danych przestrzennych) czy historycznych (inne bazy danych). Bardziej szczegółowo te kwestie zostaną omówione w dalszej części tekstu.

W komentarzu źródłoznawczym powinna zostać szczegółowo opisana metoda edycji. Procedura edytorska w przypadku map jest wieloaspektowa i wiąże się ze skanowaniem, georeferencją, wektoryzacją i opracowaniem bazy danych przestrzennych. Odpowiednikiem przygotowania publikacji do druku w przypadku edycji cyfrowych jest opracowanie aplikacji typu web GIS, która umożliwia przeglądanie edycji $\mathrm{w}$ formie cyfrowej mapy i przeprowadzanie prostych analiz przestrzennych (wyszukiwanie, zaznaczanie, selekcja warstw). Jeżeli edycja ma być rozumiana jako proces w pełni otwarty i kontynuowalny, dane powinny być także dostępne do pobrania i mieć ustaloną strukturę bazodanową. Powinny być udostępniane zgodnie z zasadami FAIR i być wyszukiwalne (findable), np. poprzez słowa kluczowe; dostępne (accessible), np. dzięki umieszczeniu ich w dostępnym repozytorium danych; interoperacyjne (interoperable) - dzięki identyfikatorom z innych zbiorów danych; gotowe do ponownego użycia (reusable) poprzez zapewnienie danym odpowiedniej licencji ${ }^{33}$. Dzięki tak przygotowanej edycji zaawansowani użytkownicy będą mogli pracować z danymi w aplikacjach typu desktop GIS, uzupełniać je i weryfikować3 ${ }^{34}$.

\section{Cyfrowa edycja mapy Gaula/Raczyńskiego na tle innych edycji cyfrowych}

Praktyczną próbą realizacji powyższych założeń było opracowanie cyfrowej edycji tzw. mapy Gaula/ Raczyńskiego, przedstawiającej zachodnią część Wielkopolski na początku XIX w. Edycja dostępna jest na stronie internetowej Atlasfontium.pl Instytutu Historii im. Tadeusza Manteuffla Polskiej Akademii Nauk $^{35}$. Składa się z następujących komponentów, których kolejność odzwierciedla etapy jej opracowania:

1) zeskanowane arkusze mapy,

2) skalibrowane i połączone arkusze,

3) arkusze ze zrekonstruowaną kolorystyką,

4) baza danych przestrzennych (geobaza),

5) skorowidz graficzny i tabelaryczny nazw,

6) aplikacja internetowa,

7) komentarz edytorski i źródłoznawczy (dokumentacja).

\section{Topograficzna, wojskowa i statystyczna mapa Wielkopolski (1807-1812)}

\section{Dzieje mapy}

Pełna nazwa mapy umieszczona na arkuszu „Śrem” to Mappa topograficzna woyskowa $i$ statystyczna części Wielkopolski, która dziś Departament Poznański składa wydana przez Edwarda Raczyńskiego Posta Poznańskiego i jego kosztem nowo układana w roku 1807-1812, a nazwa skrócona pochodzi od nazwiska fundatora (Edward Raczyński) i kartografa (Ernest Gaul) ${ }^{36}$. Mapa składa się z ośmiu arkuszy opracowywanych w latach 1807-1812, a ponieważ oryginał zaginął w czasie II wojny światowej,

${ }_{33}$ M.D. Wilkinson, M. Dumontier i in., The FAIR Guiding Principles for Scientific Data Management and Stewardship, „Scientific Data”, 3, 2016, nr 1, s. 1-9.

${ }^{34}$ M. Słoń, Pryncypia edytorstwa źródeł historycznych $w$ dobie rewolucji cyfrowej, St. Źródł., 53, 2015, s. 155-161.

$35 \mathrm{http}: / /$ atlasfontium.pl/index.php?article=gaul [dostęp: 28.10.2019].

${ }^{36}$ O mapie jak dotąd pisał B. Olszewicz (tenże, Polska kartografia wojskowa, Warszawa 1921, s. 81 n.) oraz W. Żyszkowska (taż, Mapa Wielkopolski Edwarda Raczyńskiego z lat 1807-1812, w: Kartografia polska XIX wieku w dorobku Bolesława Olszewicza, red. J. Ostrowski, W. Wernerowa, Z Dziejów Kartografii, t. 12, Wrocław-Warszawa 2000, s. 105-120; taż, Mapa Departamentu Poznańskiego Edwarda Raczyńskiego jako źródło w badaniach stanu i zmian środowiska Wielkopolski, „Biblioteka Polskiego Przeglądu Kartograficznego”, 3, 2012, s. 36-44). 
mamy do dyspozycji tylko ich fotokopie. Dwa ich komplety przechowywane są w Archiwum Państwowym w Poznaniu (sygn. M.w.36/I-VIII; 8 arkuszy), a jeden w Bibliotece Raczyńskich w Poznaniu (sygn. M II 797; 7 arkuszy) ${ }^{37}$. Oryginał przechowywany był w Bibliotece Raczyńskich (sygn. M 344) i składał się z dziewięciu arkuszy oraz dwóch mniejszych arkuszy (być może skorowidzowych?), z których na jednym znajdował się tytuł mapy ${ }^{38}$. Kopie przechowywane w Bibliotece zostały wykonane przed II wojną światową, natomiast te w Archiwum w czasie II wojny światowej, o czym świadczą niemieckie sygnatury (obecne już na skopiowanym oryginale). Niewiele wiadomo o technice wykonania fotokopii, ponieważ nie zachowała się żadna dokumentacja, nie wiemy też, dlaczego brakuje trzech arkuszy.

\section{Fundator i kartograf}

Pomysłodawcą i fundatorem mapy był hrabia Edward Raczyński (1786-1845) - poseł na sejm Wielkiego Księstwa Poznańskiego i założyciel Biblioteki Raczyńskich w Poznaniu, mający za sobą służbę w armii napoleońskiej w latach 1806-1809. Raczyński jako magnat, polityk i wojskowy był znany ze swoich kartograficznych zainteresowań - kolekcjonował mapy i rysunki techniczne. Przeznaczał także spore środki finansowe na rozwój kultury i budownictwa Wielkopolski ${ }^{39}$. Wiadomo także, że ufundował jeszcze jedną mapę, którą być może sam rysował, o czym świadczą inicjały (ER) na jednym z arkuszy. Mowa o siedmioarkuszowej mapie pt. Mappa prowincyji polskich przez Rossya zabranych, z rosyjskich kart przerobiona przez E. Raczyńskiego w r. 1810 w skali ok. 1:400 000 $0^{40}$.

Kartograf to z kolei Ernest Gaul, o którym niewiele wiadomo. Być może był to Ernst Johann Gaul, urodzony w Złotowie w 1775 r., pracujący jako mierniczy od 1789 r., a między 1807 a 1812 r. zatrudniony przez prywatną osobę do prac kartograficznych ${ }^{41}$. Inne wzmianki wskazują, że osoba o tym nazwisku pracowała w tym okresie jako Bauinspektor ${ }^{42}$ oraz Conducteur ${ }^{43}$.

\section{Skala}

Krótki komentarz należy się jeszcze skali mapy: na arkuszu zawierającym tytuł i daty opracowania skala podana jest w sposób opisowy (2000 stóp reńskich na milę niemiecką) oraz jako podziałka liniowa. $\mathrm{Z}$ tego względu oraz $\mathrm{z}$ uwagi na funkcjonujące $\mathrm{w}$ obiegu naukowym fotokopie mapy, do tej pory podawano w literaturze różne jej wartości. Wiesława Żyszkowska podaje skalę ok. 1:162 000 1:167 000, ale najprawdopodobniej określono ją na podstawie analizy kopii z Biblioteki Raczyńskich (autor niniejszego artykułu uzyskał podobne wyniki) ${ }^{44}$. Z kolei skala szacowana na podstawie pomiarów odległości między znanymi punktami na kopii z AP Poznań to ok. 1:75 000. Bolesław Olszewicz, który widział oryginał mapy przed II wojną światową, podaje skalę 1:125 $000^{45}$. Wobec powyższego można uznać, że skala oryginalnej mapy (nie fotokopii) to 1:125 000 .

\section{Zakres treści mapy}

Elementem krytyki wewnętrznej mapy jako źródła historycznego jest analiza zakresu i ujęcia treści mapy. Na wstępie należy stwierdzić, że mamy do czynienia z niedokończonym dziełem. Po pierwsze, mapa obejmuje 8 z 14 powiatów Departamentu Poznańskiego Księstwa Warszawskiego ${ }^{46}$, a opracowane

${ }^{37}$ Brakuje arkusza z powiatem krobskim.

${ }^{38}$ L. Kurtzmann, O. Sosnowski, Katalog Biblioteki Raczyńskich, Poznań 1885, s. 20.

${ }^{39}$ S. Kieniewicz, Raczyński Edward (1786-1845), iPSB, <https://www.ipsb.nina.gov.pl/a/biografia/edward-raczynski> [dostęp: 25.06.2019].

${ }^{40}$ Mapa w formie rękopiśmiennego oryginału przechowywana jest w Bibliotece Raczyńskich w Poznaniu (sygn. M II 796); więcej o mapie zob. B. Olszewicz, Polska kartografia wojskowa, s. $81 \mathrm{n}$.

${ }^{41}$ E. Börsch-Supan, Z. Ostrowska-Kębłowska, Karl Friedrich Schinkel. Die Provinzen Ost- und Westpreußen und Großherzogtum Posen, München-Berlin 2003, s. 718.

${ }^{42}$ J.C. Wutzke, Bemerkungen über die Gewässer, die Ostseeküste und die Beschaffenheit des Bodens im Königreich Preußen, Königsberg 1829, s. 118

${ }^{43}$ A. Skladny, Ein schwarzes Register aus Napoleonischer Zeit, „Zeitschrift der Historische Gesellschaft für die Provinz Posen”, 22, 1907, nr 1, s. 294.

${ }_{44}$ W. Żyszkowska, Mapa Departamentu Poznańskiego, s. 36-44.

45 B. Olszewicz, Polska kartografia wojskowa, s. 81 n.

${ }^{46}$ Babimost, Kościan, Krobia, Międzyrzecz, Oborniki, Poznań, Śrem, Wschowa. 

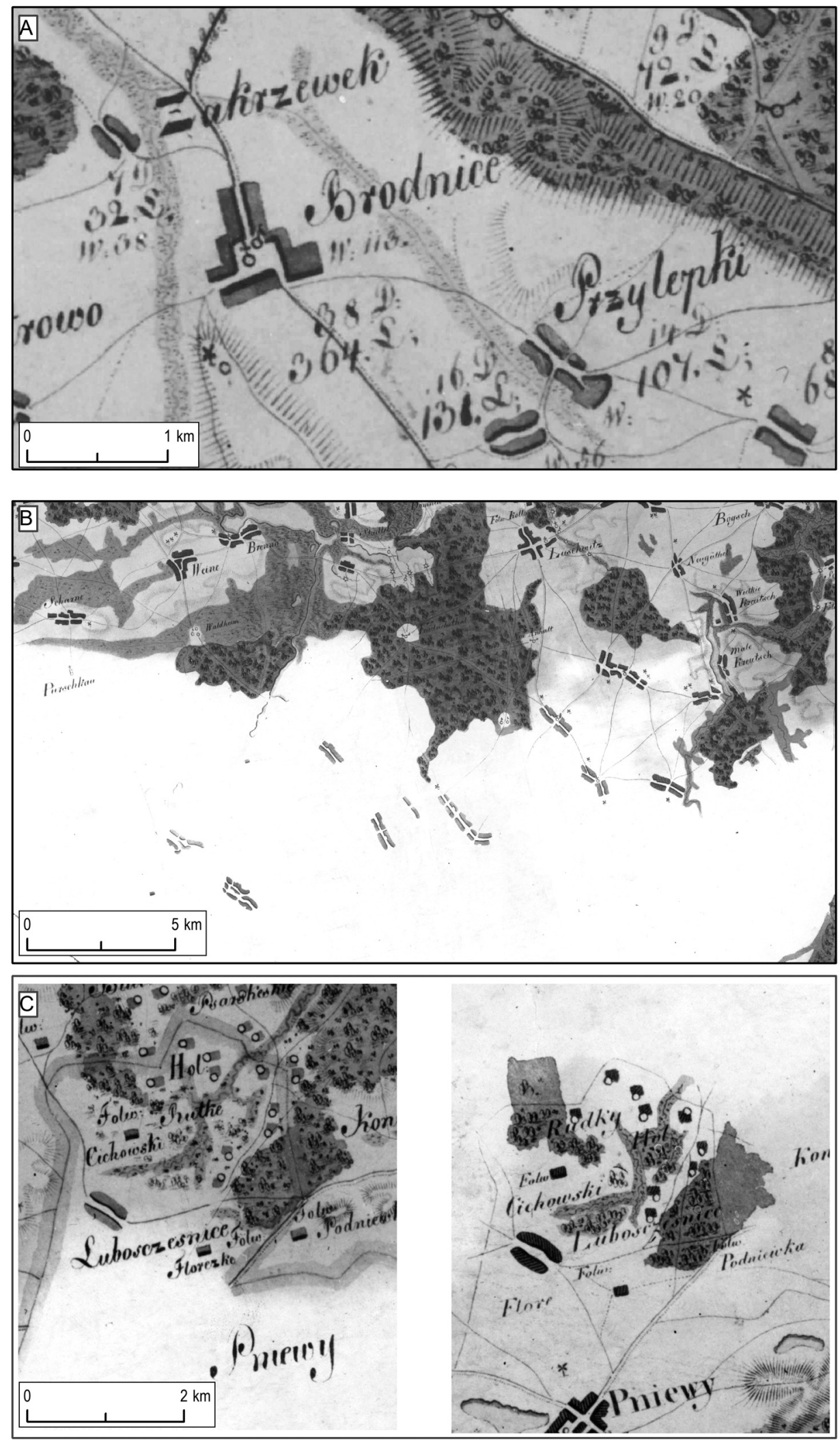

Ryc. 1. Fragmenty arkuszy mapy Gaula/Raczyńskiego: A - „Śrem” z tytułem i danymi statystycznymi (najbardziej wykończony); B - „Wschowa”, który w został skończony w ok. 25\%, a na niewykończonych fragmentach mamy np. wyłącznie rysunek zabudowy; C - „Oborniki” i „Poznan””, na których fragmenty treści są zdublowane 
A

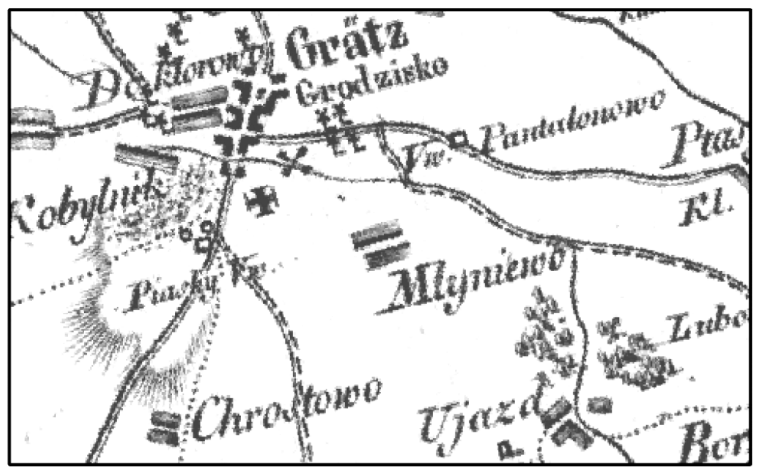

mapa Gilly'ego (1:150 000, 1802-1803)
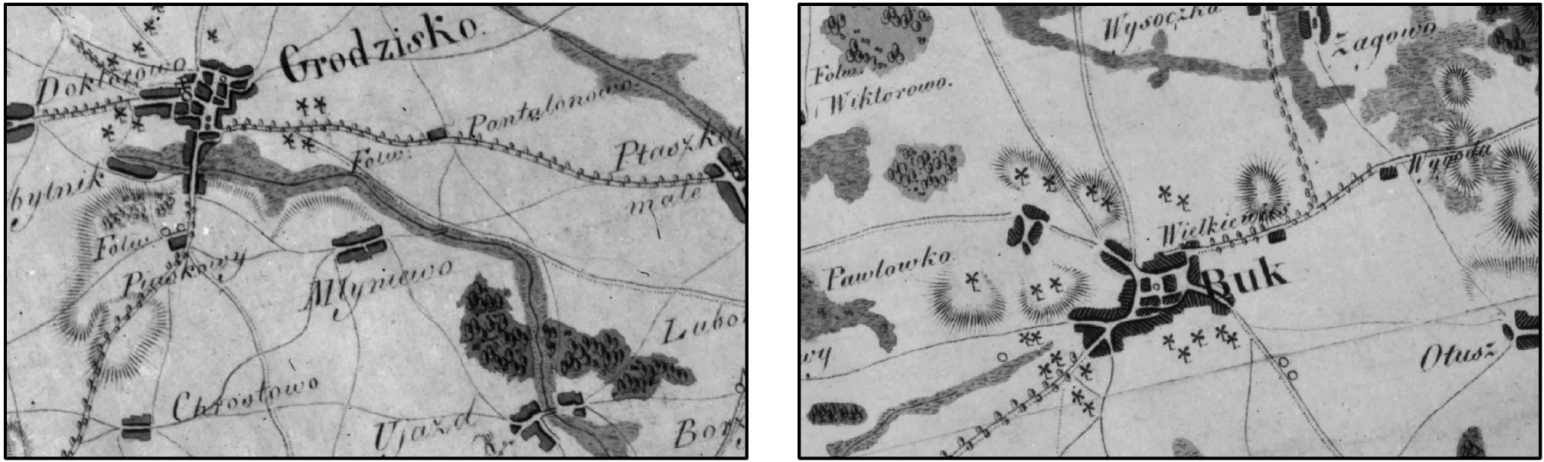

mapa Gaula/Raczyńskiego (ok. 1:125 000, 1807-1812)

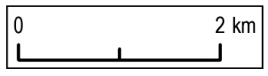

Ryc. 2. Porównanie mapy Gaula/Raczyńskiego i mapy Gilly’ego: A - Zakres treści obu map jest do siebie bardzo zbliżony; B - Różnice między mapami w kształcie zabudowy miejscowości Buk, liczby i rozmieszczenia wiatraków, elementów pokrycia terenu czy dróg

arkusze cechuje różny poziom wykończenia. Na arkuszu z powiatem śremskim mamy tytuł i podziałkę, a przy każdej miejscowości podane dane statystyczne (liczba mieszkańców, domów oraz korców wysianego zboża), na arkuszu z powiatem wschowskim brakuje niemal 3/4 treści, niepełne są również styki arkuszy z powiatami babimojskim i międzyrzeckim, a fragment treści między powiatem poznańskim i obornickim jest zdublowany (ryc. 1). Mapa pozbawiona jest w zasadzie legendy, prawdopodobnie ze względu na intuicyjność znaków oraz niewielkie grono użytkowników ${ }^{47}$, a jedyne oznaczenia dotyczą rzeźby terenu oraz danych statystycznych (arkusz „Śrem”).

Zakres treści nie odbiega, poza danymi statystycznymi, od innych map topograficznych epoki. Na treść mapy składają się:

1. Miejscowości - rozróżnione krojem pisma na miasta, miasteczka i wsi, a rodzajem zabudowy na kolonie (w większości były to wsie na prawie olęderskim, o czym świadczy przyrostek „Holl.”). $\mathrm{Na}$ arkuszu „Śrem” pod każdą miejscowością znajdują się dane statystyczne: liczba mieszkańców, domów i korcy wysianego zboża. Według legendy mapy pochodzą one ze spisów przeprowadzonych w 1809 i 1810 r. $^{48}$;

47 B. Medyńska-Gulij, T.J. Żuchowski, European Topography in Eighteenth-Century Manuscript Maps, Poznań 2018 , s. 62.

${ }^{48}$ H. Grossman, Struktura spoleczna i gospodarcza Księstwa Warszawskiego, na podstawie spisów ludności 1808 i 1810 r., „Kwartalnik Statystyczny”, 3, 1925, nr 1, passim. 
2. Obiekty gospodarcze, takie jak: folwarki, młyny, folusze czy cegielnie;

3. Drogi główne (podwójna wstęga) i poboczne (pojedyncza wstęga) z oznaczeniem drzew rosnących wzdłuż drogi;

4. Hydrografia: mniejsze rzeki reprezentowane linią, a większe oraz jeziora - powierzchnią. Obiekty hydrograficzne są w większości niepodpisane;

5. Mosty i przewozy (brody?);

6. Pokrycie terenu: lasy, łąki i bagna;

7. Rzeźba terenu oddana metodą kreskową z trzema rodzajami kresek w zależności od dostępności terenu dla pieszych, jazdy i wozów.

Już przy pobieżnej analizie treści mapy można stwierdzić, że w dużym stopniu oparto ją na tzw. mapie Gilly'ego $\left(1: 150\right.$ 000, 1802-1803 ${ }^{49}$. Nie można jednak uznać, że jest jej kopią czy przerysem, ponieważ w wielu miejscach treść mapy Gaula/Raczyńskiego jest bardziej szczegółowa, co łączy się prawdopodobnie z przeprowadzaniem dodatkowych pomiarów w terenie. Dla przykładu, na mapie Gilly'ego rzeźba terenu przedstawiona jest bardzo schematycznie, mniej jest też dróg (szczególnie niższych kategorii), a zabudowa narysowana jest z mniejszą starannością niż na mapie Gaula/ Raczyńskiego (ryc. 2).

\section{Digitalizacja mapy: skanowanie i uczytelnienie}

Pierwszym etapem opracowywania cyfrowej edycji mapy jest pozyskanie jej obrazu cyfrowego. Należy pamiętać, że proces ten nie jest w pełni wolny od błędów, a skan nie jest wierną kopią oryginału, ponieważ cechuje się pewnymi błędami, np. geometrii lub odwzorowania barw. Błędy te uzależnione są od jakości i rodzaju skanera, ale także stanu zachowania mapy ${ }^{50}$.

Wykonanie poprawnych pod względem odwzorowania geometrii skanów było istotnym problemem. Arkusze dostępne w AP Poznań były na ogół dobrej jakości, poza arkuszem z powiatem śremskim i międzyrzeckim, które były nieumiejętnie podklejone na płótnie (arkusz „Śrem”) albo wielokrotnie składane (arkusz „Międzyrzecz”). Okazało się jednak, że mają one wymiary przekraczające rozmiar dostępnego tam skanera, pierwszą próbą było więc zeskanowanie ich w kilku częściach przy zastosowaniu zakładki. Nie dało się ich jednak połączyć ze względu na błędy geometrii skanera, dochodzące nawet do kilku milimetrów, co w skali mapy przekładało się na kilkaset metrów. Podjęto zatem próbę zeskanowania mapy na specjalnym skanerze do map wielkoformatowych. Próby te okazały się pomyślne, dzięki czemu otrzymano skany w wysokiej jakości i o niewielkich już błędach geometrii. Pozyskano także skany z Biblioteki Raczyńskich, jednak zachowane tam fotokopie były wyraźnie gorszej jakości niż te z Archiwum, brakowało także jednego arkusza (powiatu krobskiego). Z drugiej strony pozbawione były - nadanych najprawdopodobniej przez niemieckich archiwistów w czasie II wojny światowej - sygnatur archiwalnych.

Wobec braku barwnego oryginału i mając do dyspozycji dwie różniące się od siebie czarno-białe kopie mapy, w pracach edytorskich zdecydowano się na rekonstrukcję jej oryginalnego wyglądu, co można porównać do odtworzenia tzw. archetypu źródła ${ }^{51}$. Podstawą archetypu był skan z AP Poznań, zarówno ze względu na dobry stan kopii, jak i z powodu bardzo dobrej jakości skanu i niskich zniekształceń geometrii. Skan ten został wyretuszowany w miejscach, w których pojawiały się sygnatury: niemieckie (z czasów II wojny światowej) oraz polskie (z Biblioteki Raczyńskich), jak również wyczyszczono go $\mathrm{z}$ artefaktów powstałych w wyniku skanowania oraz poprawiono geometrię w miejscach ewidentnych błędów skanera (ryc. 3).

49 D. Gilly, Langner, W.H. Matthias, Special Karte von Suedpreussen mit allerhoechster Erlaubniss aus der Koniglichen grossen topographischen Vermessungs-Karte, unter Mitwürkung des Directors Langner, reducirt und herausgegeben vom Geheimen Ober-Bau-Rath Gilly... die Post-Course und Hauptstrassen sind gezeichnet vom ersten General Post Amst, 1:150 000, Berlin 1802-1803.

50 Z. Xie, Q. Jiang, H. Wu, B. Fu, Uncertainty Analysis of Map Scanning Digitization and Data Quality Control, w: 2010. $18^{\text {th }}$ International Conference on Geoinformatics, b.m.w. 2010, s. 1-4.

${ }^{51}$ J. Tandecki, K. Kopiński, Edytorstwo źródeł historycznych, s. 135. 

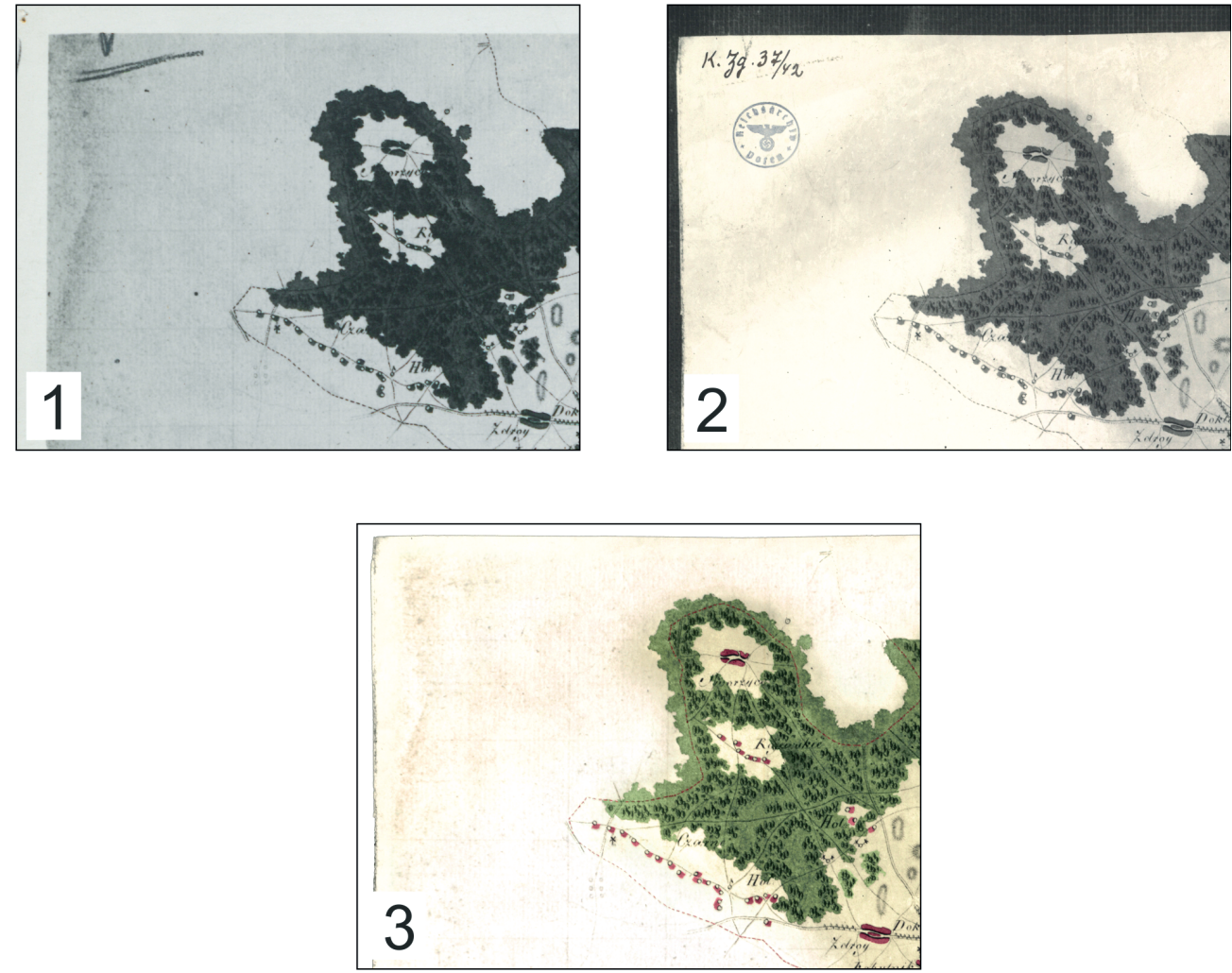

Ryc. 3. Metaarkusze mapy Gaula/Raczyńskiego

Istotnym elementem w rekonstrukcji archetypu było przywrócenie barw czarno-białej kopii. Rekonstrukcja kolorystyki przebiegała w dwóch etapach. Pierwszy polegał na wektoryzacji (przerysowaniu) treści mapy w programie graficznym (Adobe Photoshop) i klasyfikacji elementów jednolitych pod względem maniery rysunku. Drugim etapem było nadanie odpowiednich barw poszczególnym elementom rysunku: lasom, rzekom, zabudowie, etc. (ryc. 4). Wzorowano się na innych mapach rękopiśmiennych (zachowanych w oryginale) z tego okresu, m.in. mapie von Schmettaua ${ }^{52}$, von Pfaua ${ }^{53}$, Gilly'ego-Crona $^{54}$, zdjęciu terezjańsko-józefińskim (mapy Miega i Heldensfelda) ${ }^{55}$ czy mapach Cassiniego ${ }^{56}$. Główną wątpliwością był kolor lasów, na pruskich mapach z tej epoki lasy były bowiem ciemnoszare, a nie zielone - jak na mapach francuskich (Cassini), ale także włoskich ${ }^{57}$ czy angielskich $^{58}$. Co ciekawe, według instrukcji lasy, zarówno liściaste, jak i iglaste, powinny były być przedstawiane zieloną barwną na mapach rękopiśmiennych i drukowanych (kolorowanych) ${ }^{59}$. Istotnym pytaniem jest zatem, którą „szkołą” kierował się kartograf: pruską (niemieckie pochodzenie E. Gaula - kartografa) czy francuską (związki polityczno-wojskowe E. Raczyńskiego z Francją napoleońską)? Jesteśmy w stanie

52 A. Konias, Kartografia topograficzna, s. 25-29, Staatsbibliothek zu Berlin: L 5421.

53 Tamże, s. 109-112, Staatsbibliothek zu Berlin: Q 16939/6-Q 16939/10.

${ }_{54}$ Tamże, s. 119-121, Staatsbibliothek zu Berlin: N14431.

${ }^{55}$ G. Molnár, G. Timár, E. Biszak, Can the First Military Survey Maps of the Habsburg Empire (1763-1790) be Georeferenced by an Accuracy of 200 Meters?, w: $9^{\text {th }}$ International Workshop on Digital Approaches to Cartographic Heritage, Budapest, 4-5 September 2014, < https://www.arcanum.hu/media/uploads/mapire/pub/1survey molnar et al.pdf $>$ [dostęp: 16.09.2020]. Mapy dostępne na portalu Mapire. The Historical Map Portal.

${ }^{56}$ Mapy dostępne na francuskim geoportalu Géoportail <https://www.geoportail.gouv.fr/> [dostęp: 20.04.2020] oraz w projekcie GeoHistoricalData <http://www.geohistoricaldata.org/> [dostęp: 20.04.2020].

57 B. Medyńska-Gulij, T.J. Żuchowski, European Topography, s. 106 n.

58 Tamże, s. 138 n.

59 Tamże, s. 63 n.; L. Müller, Vorschriften zu militarischen Plan- und Carten Zeichungen, Potsdam 1782. 

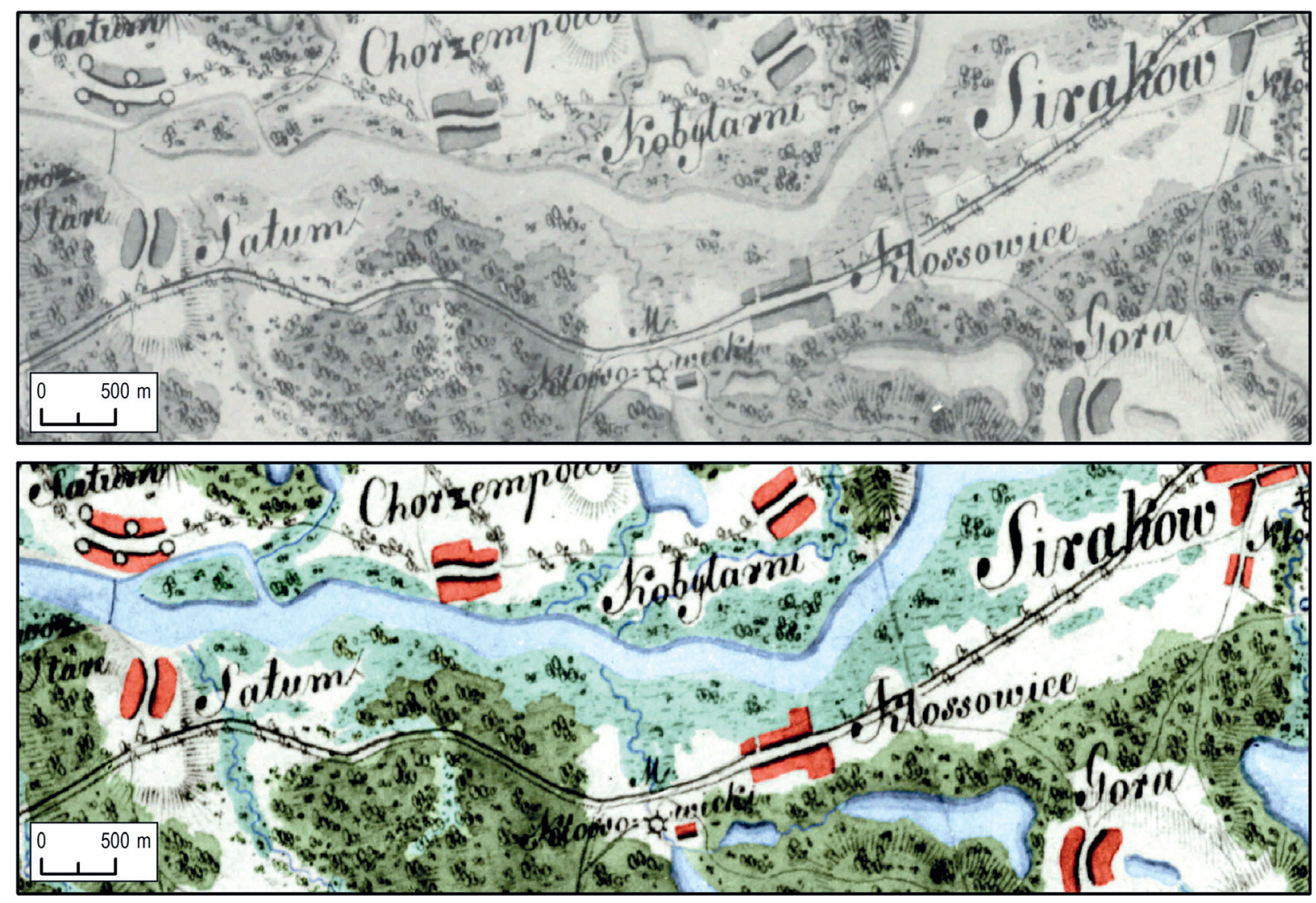

Ryc. 4. Rekonstrukcja barw mapy Gaula/Raczyńskiego

stwierdzić, że maniera rysunku mapy Gaula/Raczyńskiego bardziej przypomina mapy francuskie (dosyć miękkie symbole i delikatna kreska) niż pruskie. Zdecydowaliśmy się zatem zastosować schemat barw zbliżony do francuskich (lasy zielone).

Należy zaznaczyć, że rekonstrukcja barw ma charakter hipotetyczny, ale dzięki niej mapa jest znacznie bardziej czytelna dla współczesnego użytkownika. Tak opracowane arkusze mapy (jak również wersje bez ingerencji edytorskich) są dostępne do pobrania i stanowią niejako pierwszy etap cyfrowej edycji tego zabytku.

Należy podkreślić, że bardzo wiele współczesnych edycji opiera się jedynie na udostępnieniu skanów i poprzestaje na tym etapie. Należą do nich biblioteki cyfrowe z zasobami kartograficznymi czy kolekcje dawnych map, w tym np. David Rumsey Historical Map Collection (https://www.davidrumsey.com/; dostęp: 21.11.2019). Mamy jednak do czynienia także z projektami, w których obraz mapy poddawany jest retuszowi, jak np. w przypadku cyfrowej edycji mapy z Hereford (https://www. themappamundi.co.uk/mappa-mundi/; dostęp: 17.12.2019).

\section{Kalibracja i mozaikowanie}

Skanowanie i opracowanie archetypu źródła pozwoliło na dalsze prace edytorskie mające na celu udostępnienie mapy w aplikacji typu web GIS. Przystąpiono do nadania mapie georeferencji, tj. dopasowania jej do współczesnego układu współrzędnych w programie GIS za pomocą punktów dostosowania zidentyfikowanych na mapie dawnej i współczesnej ${ }^{60}$. Ten zabieg miał na celu uwspółcześnienie treści mapy poprzez nałożenie jej na współczesną mapę topograficzną oraz umożliwienie wykonania

${ }^{60}$ A. Affek, Kalibracja map historycznych z zastosowaniem GIS, w: Źródta kartograficzne w badaniach krajobrazu kulturowego, red. J. Plit, J. Nita, Prace Komisji Krajobrazu Kulturowego, t. 16, Sosnowiec 2012, s. 48-62. 


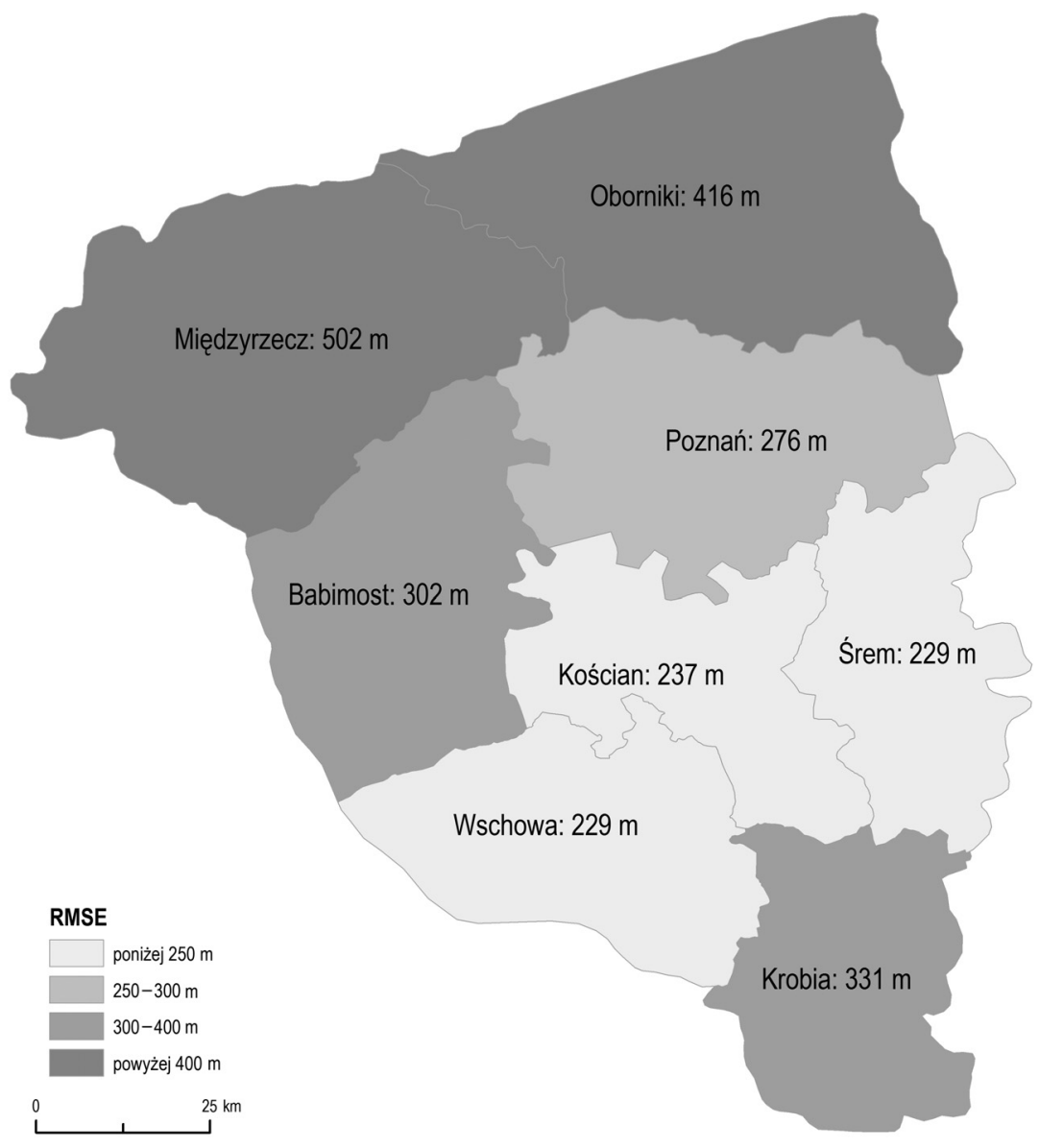

Ryc. 5. Dokładność kalibracji poszczególnych arkuszy mapy

kolejnego etapu - opracowania przestrzennej bazy danych ${ }^{61}$. W procesie georeferencji map dawnych kluczowa jest dokładność ich wpasowania w układ współczesny. Dokładność mierzona jest średnim błędem kwadratowym (RMSE - Root Mean Square Error) i nigdy nie będzie równie wysoka, jak w przypadku map współczesnych, a na efekt końcowy wpływa wiele czynników, począwszy od stopnia dokładności samej mapy, stanu jej zachowania, błędów geometrii przy skanowaniu, ale także liczby i charakteru punktów kontrolnych czy zastosowanego algorytmu transformacji. W przypadku mapy Gaula/Raczyńskiego zdecydowano się na transformację liniową (Helmerta) z kilkunastoma, maksymalnie kilkudziesięcioma punktami kontrolnymi na każdym arkuszu - przeważnie były to kościoły istniejące 200 lat temu i dzisiaj. Ten rodzaj transformacji zapewnia wpasowanie mapy w docelowy układ współrzędnych przy jednoczesnym braku zniekształceń obrazu. Błędy wahały się od $229 \mathrm{~m}$ (arkusze „Śrem” i „Wschowa”), przez ok. 200-300 m aż do ok. 500 m (arkusz „Międzyrzecz”) (ryc. 5). Błąd oscylujący wokół 200-300 m należy uznać za bardzo dobry wynik, szczególnie w porównaniu z innymi mapami z epoki ${ }^{62}$. Około $229 \mathrm{~m}$ błędu na arkuszu „Śrem” może wynikać z faktu, że jest on w największym stopniu wykończony, natomiast znacznie większy błąd na arkuszu „Międzyrzecz” z faktu jego nie najlepszego stanu fizycznego, szczególnie zagięć.

${ }^{61}$ Dla map z epoki pomiarowej, które cechuje odpowiedni stopień kartometryczności, opracowywana baza danych powinna być poprzedzona kalibracją mapy. Bazę można także opracować dla map niekartometrycznych, ale wówczas wybrane obiekty zaznaczane są na skanie pozbawionym kalibracji i odnoszone, np. poprzez identyfikator do danych georeferencyjnych.

${ }^{62}$ S. Pietkiewicz, Analiza dokładności niektórych map z XVII, XVIII i XIX wieku, obejmujacych Polskę w dawnych granicach, „Prace i Studia Geograficzne”, 17, 1995, s. 103-109. 
Kolejnym etapem było mozaikowanie arkuszy, czyli połączenie ich w jednolity obraz, dzięki czemu użytkownik może posługiwać się mapą jako całością, co znacznie zwiększa użyteczność edycji. Z dwóch względów jest to jednak poważny zabieg edytorski. Po pierwsze dlatego, że arkusze mapy najprawdopodobniej nie były (w stanie takim, w jakim je opracowano) przewidziane do łączenia. Po drugie, ponieważ część treści, np. nachodzącej na siebie z dwóch arkuszy, po ich połączeniu ulega usunięciu i będzie już dalej widoczna tylko na jednym z nich (por. ryc. 1-C). Z tego też względu istotne było zachowanie - jako komponentu edycji - także arkuszy niepołączonych. Jest to jednocześnie swego rodzaju dokumentacja edycji możliwa do osiągnięcia dzięki narzędziom cyfrowym. Samo połączenie arkuszy polegało na przycięciu ich w taki sposób, aby treść sąsiadujących arkuszy nie nakładała się na siebie, ale płynnie przechodziła z arkusza na arkusz. Proces ten, podobnie jak kalibracja, cechował się pewnym stopniem dokładności (ryc. 6).
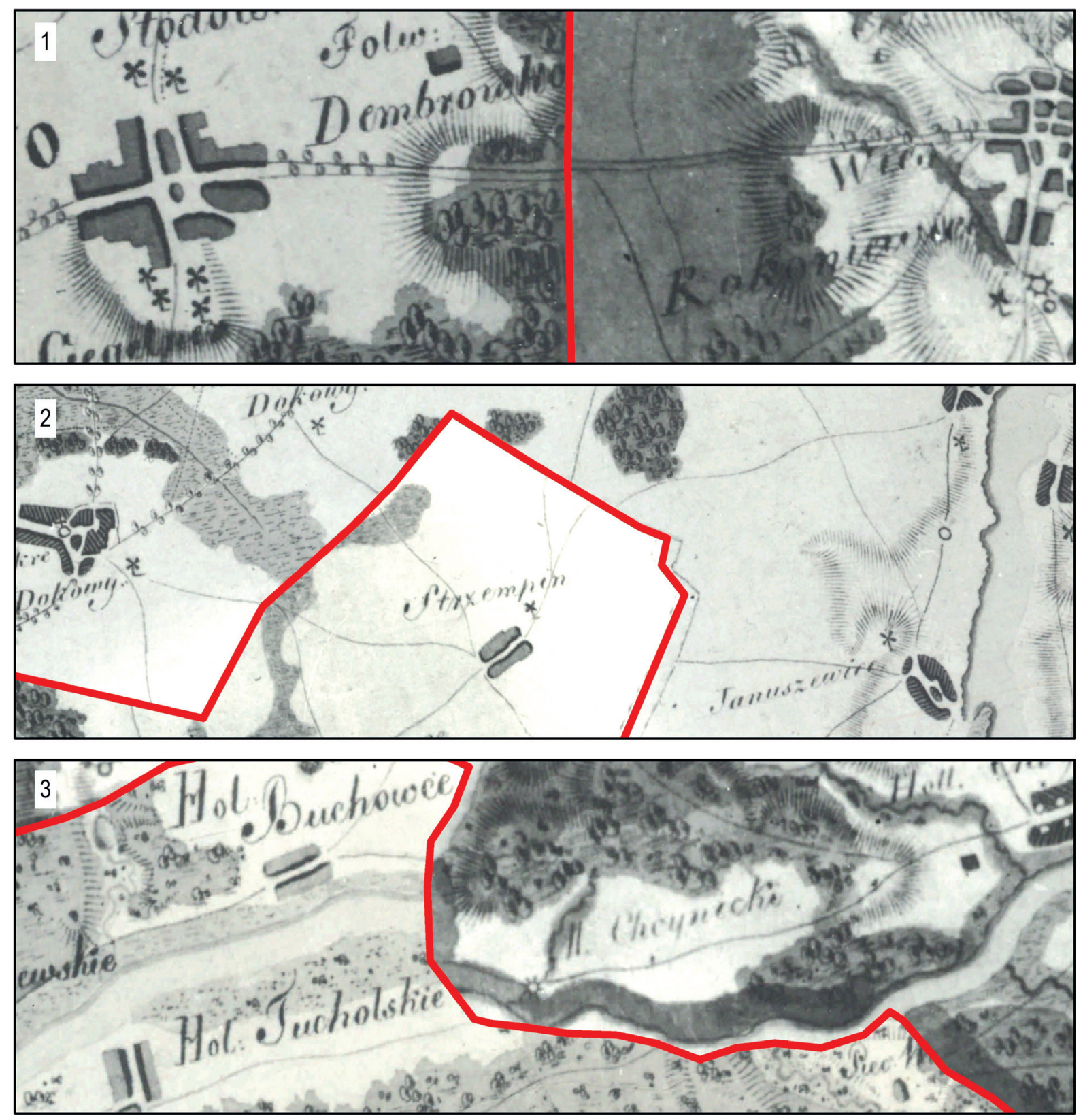

Ryc. 6. Przykłady łączenia arkuszy mapy Gaula/Raczyńskiego 
Największą dokładność, tj. sytuację, gdy treść sąsiadujących arkuszy łączy się ze sobą niemal idealnie bądź z niewielkimi tylko odchyleniami, można zaobserwować między arkuszami „Babimost” i „Kościan”. Niekiedy jednak te odchylenia są większe, ale nie mają wpływu na czytelność mapy, np. między arkuszami „Kościan” a „Poznan”. Największe błędy dostrzeżono na stykach arkuszy „Kościan” i „Śrem” oraz „Oborniki” i „Międzyrzecz”, szczególnie na linii Warty. Jedyną możliwością rozwiązania tego problemu byłoby wykorzystanie bardziej zaawansowanych metod kalibracji mapy, które jednak w dosyć znaczny sposób zniekształciłyby jej obraz ${ }^{63}$. Zdecydowano się świadomie na pozostawienie niedoskonałego połączenia, m.in. w celu pokazania, w których miejscach tzw. mapa Gaula/Raczyńskiego rzeczywiście jest mapą bardzo dokładną, a w których nie.

Dzięki temu etapowi prac użytkownikom udostępniono skalibrowaną i połączoną mapę, którą można przeglądać w aplikacji internetowej na stronie z edycją, wczytać do programu desktop GIS za pomocą usług danych przestrzennych WMS (Web Map Service), ale również pobrać w formie wysokorozdzielczych plików *.tiff. Takie rozwiązanie zapewnia otwartość edycji i umożliwia dalsze prace z materiałem przez różne grupy użytkowników. Docelowo edycja (zarówno mapy, jak i dane) mogą stać się elementem urzędowego Geoportalu (https://www.geoportal.gov.pl/; dostęp: 31.12.2019).

Skalibrowane mapy dawne są bowiem elementem geoportali z danymi współczesnymi oraz dedykowanymi mapom dawnym. Do tej pierwszej grupy można zaliczyć geoportale: francuski (https:// www.geoportail.gouv.fr/; dostęp: 21.11.2019) i niemiecki (https://bb-viewer.geobasis-bb.de/; dostęp: 21.11.2019). Obydwa prezentują współczesne, referencyjne dane geograficzne różnych rodzajów, ale ich elementem są także skalibrowane i zmozaikowane mapy dawne. W przypadku Francji jest to mapa Cassiniego (XVIII w.) oraz Carte de l'état Major (XIX w.), a Brandenburgii zbiór map von Schmettaua (XVIII w.) oraz seria map topograficznych Messtischblätter (przełom XIX i XX w.). Umieszczenie map dawnych w zasobach państwowych geoportali umożliwia nie tylko odniesienie współczesnej informacji geograficznej do danych historycznych, ale świadczy także o istotnej roli dawnej kartografii jako elementu dziedzictwa kulturowego.

Drugim rodzajem geoportali są te wyłącznie z mapami dawnymi, a do najważniejszych należą wspomniany wcześniej Mapire. The Historical Map Portal (https://mapire.eu/en/; dostęp: 23.10.2019) oraz Mapy z przeszłością (http://hgis.cartomatic.pl/; dostęp: 21.11.2019). Na obydwu prezentowane są skalibrowane i zmozaikowane serie map topograficznych, z których najwcześniejsze były opracowane w końcu XVIII w. (zdjęcie terezjańsko-józefińskie). Funkcjonalność geoportali dotyczy jednak głównie przeglądania zasobów, a nie ich pobierania (w odróżnieniu od bibliotek cyfrowych czy kolekcji), chociaż możliwość bezpłatnego pobrania skanów map pojawia się na portalu A Vision of Britain (http:// www.visionofbritain.org.uk/maps/; dostęp: 21.11.2019). Obydwa wspomniane na początku geoportale udostępniają swoje dane poprzez usługi danych przestrzennych, chociaż w przypadku portalu Mapire jest to płatne.

\section{Opracowanie przestrzennej bazy danych}

Kolejnym etapem w pracach edytorskich jest digitalizacja treści mapy, tj. wektoryzacja wybranych elementów jej treści i umieszczenie ich w specjalnie opracowanej bazie danych przestrzennych. Jest to jeden z najważniejszych komponentów cyfrowej edycji mapy, ponieważ dzięki niemu możliwe jest wyszukiwanie obiektów według nazwy, typu czy lokalizacji. Wektoryzacja pełni rolę odczytu tekstu źródła oraz indeksu geograficznego i rzeczowego. Opracowywanie takich baz przeważnie rozpoczyna się od przestudiowania legendy, a następnie transformacji zakresu treści mapy do struktury informatycznej ${ }^{64}$. Ze względu na brak klucza znaków na mapie Gaula/Raczyńskiego konieczna była pełna analiza zakresu treści mapy i de facto rekonstrukcja jej legendy, co dotyczyło wszystkich elementów rysunku

${ }^{63}$ G. Molnár, Making a Georeferenced Mosaic of Historical Map Series Using Constrained Polynomial Fit, „Acta Geodaetica et Geophysica Hungarica", 45, 2010, nr 1, s. 24-30.

${ }^{64}$ A. Głażewski, Modele rzeczywistości geograficznej a modele danych przestrzennych, „Polski Przegląd Kartograficzny”, 38, 2006, nr 3, s. 217-225. 
mapy. Z uwagi na modelowy charakter edycji zdecydowano się przygotować bazę danych będącą niemal kompletną, cyfrową reprezentacją treści mapy. Zakres treści bazy danych jest zatem prawie całkowitą reprezentacją treści mapy (oprócz rzeźby terenu) i składają się na nią następujące warstwy.

\section{Miejscowości}

Miejscowości oznaczane na mapie to miasta, miasteczka, wsi oraz kolonie wyróżnione na podstawie różnic w graficznej reprezentacji opisów lub zabudowy na mapie. Do bazy danych wprowadzano informacje o lokalizacji miejscowości (jako punkty), nazwie z mapy, charakterze (typie) oraz danych statystycznych (arkusz „Śrem”). Uwzględniono także nazwę współczesną, poprzez identyfikację miejscowości z mapy ze współczesnymi mapami, a głównym kryterium utożsamienia była lokalizacja oraz nazwa własna. W sumie na mapie wyróżnionych zostało 1595 miejscowości, z czego 2 miasta (Poznań i Kościan), 63 miasteczka, 1290 wsi i 240 kolonii.

\section{Obiekty przemystowe}

Obiekty przemysłowe reprezentują obszary pełniące przede wszystkim funkcję przemysłową i gospodarczą, składające się z więcej niż jednego budynku albo zajmujące pewien obszar terenu. Na mapie (i w bazie danych) wyróżniono sześć ich typów: cegielnie, smolarnie, folwarki, owczarnie, piece wapienne, a także zakłady przemysłowe o nieustalonej funkcji szczegółowej (reprezentowane znakiem podobnym do cegielni i smolarni, ale bez opisu kategorii).

\section{Budynki i konstrukcje}

Budynki i konstrukcje reprezentują trwałe struktury antropogeniczne jednolite pod względem pełnionej funkcji. Na mapie są to: domy, folusze, kaplice, karczmy, klasztory, kościoły, leśniczówki, młyny, mosty oraz przeprawy, wiatraki, zamki. W tej klasie umieszczono razem przewozy przez rzekę (,,przewóz") oraz mosty, ze względu na brak różnicy graficznej między tymi dwoma kategoriami. Odróżnienie „budynków i konstrukcji” od „obiektów przemysłowych” wynikało z chęci dostosowania modelu danych do tego z Bazy Danych Obiektów Topograficznych (BDOT10k), w którym osobną klasę obiektów stanową obszary pełniące jednolitą funkcję (tu „obiekty przemysłowe”) oraz budynki ${ }^{65}$.

\section{Nazwy fizjograficzne}

Na mapie Gaula/Raczyńskiego znalazło się zaledwie 21 nazw, które dotyczą różnych obiektów fizjograficznych, głównie bagien, wzniesień i rzek.

\section{Drogi}

Do bazy wprowadzano tylko geometrię głównych dróg (podwójna wstęga), jednak w niektórych miejscach uzupełniono rysunek o drogi boczne, aby zachować sieciowy charakter dróg.

\section{Hydrografia}

Jako hydrografię liniową ujęto rzeki, natomiast powierzchniową - jeziora oraz rzeki, które na mapie Gaula/Raczyńskiego były pokazane powierzchnią.

\section{Pokrycie terenu}

Jako elementy pokrycia terenu w bazie umieszczono lasy oraz bagna. Celowo zrezygnowano z zabudowy, uznano bowiem, że jej obraz w tej skali jest już dosyć mało wiarygodny ze względu na stosowanie znaków nieskalowych i przewiększanie małych powierzchni.

\section{Granice}

Powierzchnią oddano granice (obszary) poszczególnych powiatów.

${ }^{65}$ BDOT, Opis baz danych obiektów topograficznych i ogólnogeograficznych oraz standardy techniczne tworzenia map, t. 1 , Dz.U., 2011, nr 279, poz. 1642. 


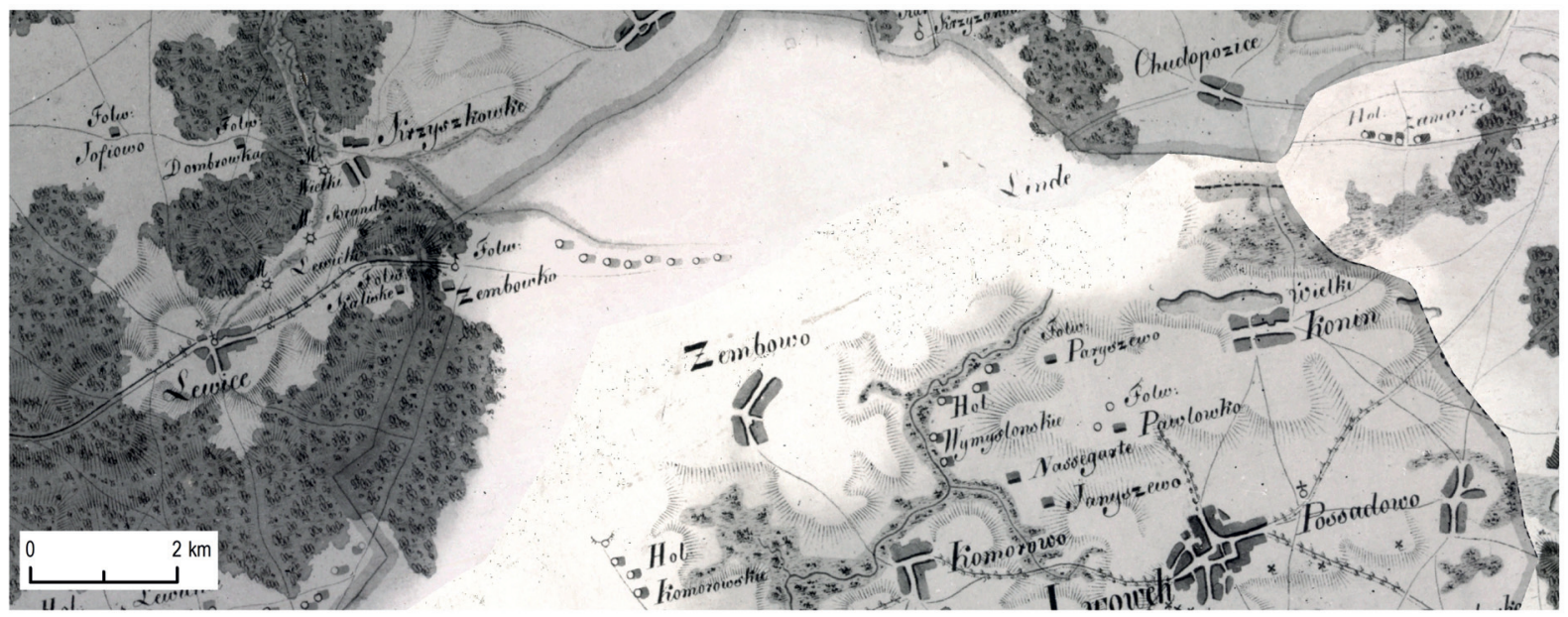

mapa Gaula/Raczyńskiego

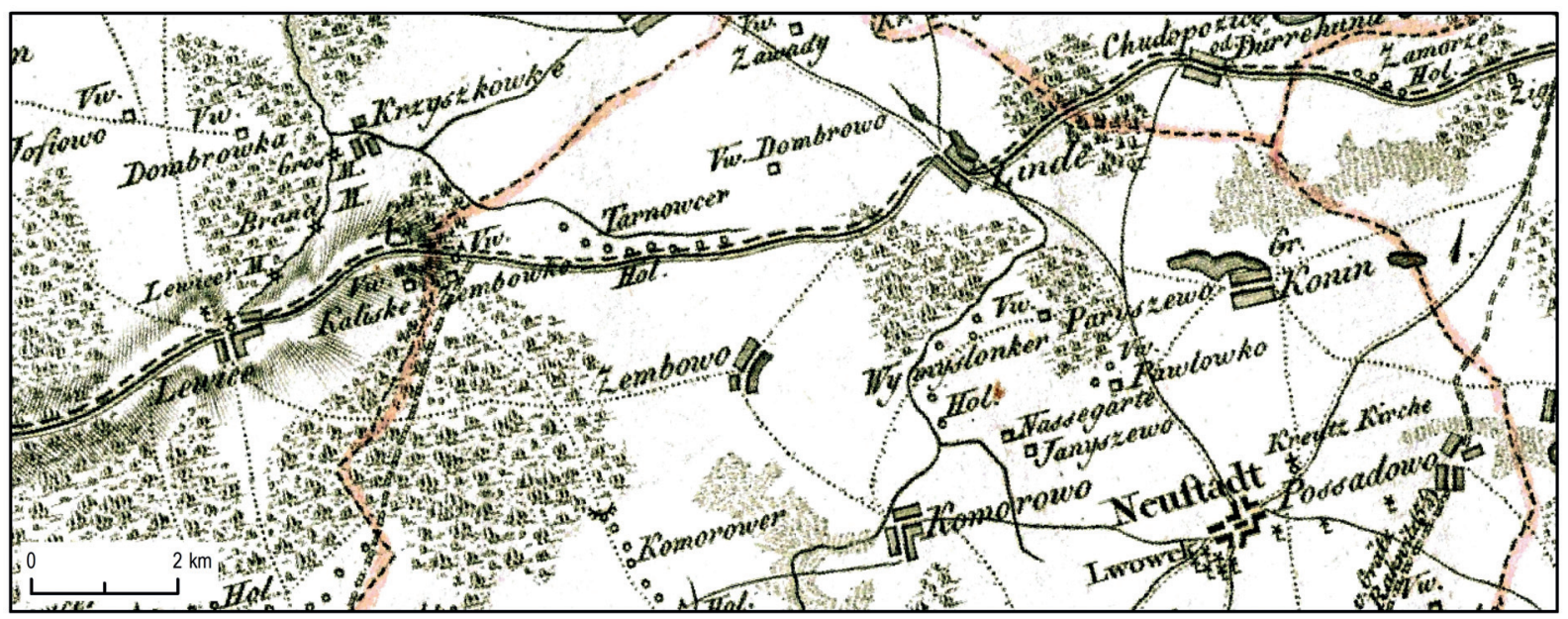

mapa Gilly'ego

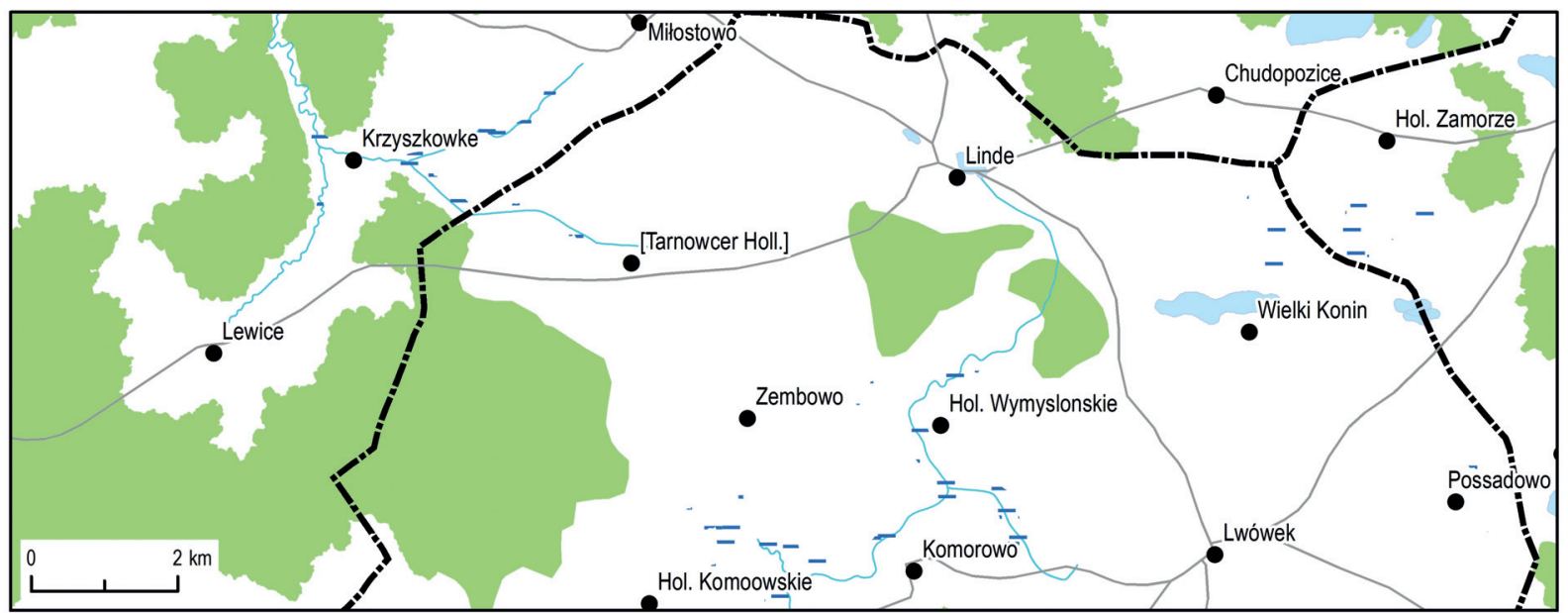

cyfrowa edycja mapy Gaula/Raczyńskiego

Ryc. 7. Uzupełnianie przestrzennej bazy danych na podstawie mapy Gilly’ego. Położenie, typ i nazwa miejscowości [Tarnowcer Holl.] zostały określone na podstawie mapy Gilly’ego 
Problemem w opracowaniu bazy danych była nieciągłość treści mapy, która w wielu miejscach była niedokończona. I tak, na pograniczu arkuszy „Babimost” i „Międzyrzecz” mamy do czynienia z „białymi plamami”, które uzupełniono, posiłkując się mapą Gilly’ego, która - jak już wspomniano - była najprawdopodobniej głównym materiałem źródłowym (ryc. 7). Fakt ten odnotowano w bazie i każdy tak rekonstruowany obiekt ma odpowiedni atrybut. Ten zabieg można porównać do odtworzenia nieczytelnego fragmentu pisma w rękopisie.

Opracowaną bazę danych można przeglądać na dwóch poziomach. Po pierwsze w aplikacji internetowej, wraz ze skalibrowaną i połączoną mapą, a po drugie jako geobazę do pobrania. Dzięki temu użytkownicy mogą bezpośrednio skorzystać z zebranych danych i wykorzystywać je do własnych analiz. Obiekty o geometrii punktowej, takie jak miejscowości czy zakłady gospodarcze, zostały połączone poprzez identyfikatory z Państwowym Rejestrem Nazw Geograficznych (PRNG), co umożliwia łączenie ich z innymi zasobami danych geohistorycznych ${ }^{66}$. Taka filozofia publikacji i udostępniania danych jest praktyczną realizacją edycji otwartej ${ }^{67}$.

Żadna $\mathrm{z}$ dotychczas opracowanych w podobny sposób cyfrowych edycji map nie zapewnia takich funkcjonalności. Francuski projekt „Des villages de Cassini aux communes d'aujourd'hui” dotyczy krytycznego opracowania danych z mapy Cassiniego: miejscowości i podziałów administracyjnych XVIII-wiecznej Francji ${ }^{68}$. Projekt ten można uznać bardziej za wykorzystanie mapy do przedstawienia pewnego zagadnienia, ale z pewnością ma on również cechy edycji: facsimile źródła wraz ze zrekonstruowaną legendą, indeks miejscowości oraz komentarz, dane te nie są jednak dostępne do pobrania. W kontynuacji tego projektu, tj. GeoHistoricalData (http://www.geohistoricaldata.org/; dostęp: 21.11.2019) wprawdzie można pobrać dane wektorowe, ale skalibrowanych i połączonych arkuszy mapy Cassiniego już nie ${ }^{69}$. Projekt „Beauplan's Ukraine” zapewnia z kolei dostęp do danych przestrzennych w formie cyfrowego gazetera, ale w ogóle nie uwzględnia skanów map ${ }^{70}$.

\section{Opracowanie aplikacji typu web GIS}

Wyżej opisane dane, tj. skalibrowane arkusze map w wersjach czarno-białej i kolorowej oraz baza danych przestrzennych udostępniane są w aplikacji internetowej typu web GIS. Pozwala ona na wyświetlanie warstw informacji oraz podstawowe zapytania atrybutowe i przestrzenne. Można np. wyszukać miejscowości według nazwy, wyświetlić miejscowości tylko w danym powiecie (zapytania przestrzenne) albo podstawowe informacje o każdym z obiektów, a także wyeksportować dane do arkusza kalkulacyjnego.

\section{Redakcja komentarza edytorskiego i źródtoznawczego}

Pełny komentarz dotyczący opisu mapy oraz ingerencji edytorskich jest dostępny wraz z cyfrową edycją na stronie projektu. Znajduje się tam opis mapy, jej losów, zakresu treści i sposobu opracowania, opisy fizyczne arkuszy mapy (stan zachowania, porównanie między kopiami, etc.), a także szczegółowe omówienie procedury edytorskiej.

\footnotetext{
${ }^{66}$ Metodologia tworzenia czasowo-przestrzennych baz danych dla rozwoju osadnictwa oraz podziałów terytorialnych, red. B. Szady, [raport z projektu: „Ontologiczne podstawy budowy historycznych systemów informacji geograficznej”. Jednostka naukowa: Instytut Historii im. Tadeusza Manteuffla Polskiej Akademii Nauk. Kierownik projektu: dr hab. prof. IH PAN Bogumił Szady], 2019.

${ }^{67}$ M. Słoń, Sine initio et sine fine, s. 131-142.

${ }^{68}$ C. Motte, M.-Ch. Vouloir, Le site cassini.ehess.fr un instrument d'observation pour une analyse du peuplement, „Bulletin du Comité français de cartographie", 191, 2007, s. 68-84.

${ }^{69}$ J. Perret, M. Gribaudi, M. Barthelemy, Roads and Cities of $18^{\text {th }}$ Century France, ,Scientific Data”, 2, 2015, <https://www. nature.com/articles/sdata201548> [dostęp: 16.09.2020].

${ }^{70}$ M. Polczynski, M. Polczynski, Beauplan's Ukraine. Open Access Georeferenced Databases for Studies of Early Modern History of Central and Eastern Europe, „Miscellanea Geographica”, 23, 2019, nr 3, s. 185-193.
} 


\section{Podsumowanie i dyskusja}

Idąc za definicją Patricka Sahlego, można stwierdzić, że edycja źródła kartograficznego to krytyczna, udokumentowana reprezentacja rozumiana jako rekodowanie źródła i jego treści oraz jego ponowny zapis w formie czytelnej dla współczesnych użytkowników ${ }^{71}$. W podsumowaniu należy zwrócić jeszcze uwagę na istotne aspekty cyfrowego edytorstwa źródeł kartograficznych: różnice między edycją tekstu a mapy, kwestię naukowego i popularnonaukowego udostępniania map, rolę narzędzi cyfrowych w procesie wydawania źródeł kartograficznych, relacje między edycją mapy a kartografią historyczną oraz stabilność i utrzymanie cyfrowych projektów.

\section{Edycja mapy a edycja tekstu}

Metodyka edycji map wywodzi się z metodyki edycji źródeł pisanych, ale ze względu na odmienny charakter źródeł wymaga specyficznego postępowania. Tekst jest (przeważnie) linearnym ciągiem znaków, a źródło kartograficzne składa się z rozmieszczonych w przestrzeni dwuwymiarowej symboli przeplatających się z opisami tekstowymi. Mapy stanowią graficzną reprezentację rzeczywistości geograficznej, a co za tym idzie preferowaną formą ich edycji jest forma graficzna, np. facsimile albo skan. Edycje źródeł pisanych to wciąż przeważnie pełen odczyt, rzadziej facsimile, zarówno ze względu na ograniczenia technologiczne, jak również fundamentalne znaczenie przepisania tekstu $\mathrm{w}$ procesie edytorskim ${ }^{72}$. Nie jest to jednak jedyna różnica. O ile w przypadku źródeł pisanych pełen odczyt oraz indeksy są pewnym standardem, to w przypadku publikowania źródeł kartograficznych bardzo często poprzestaje się na skanie mapy bez indeksacji i transkrypcji jej treści. Co za tym idzie, nie mamy wówczas do czynienia ze względnie pełną edycją źródła, a jedynie pewnym etapem w procesie edytorskim.

\section{Naukowe i popularnonaukowe edytorstwo map}

Publikowanie obrazu mapy pozbawionego odczytu (wektoryzacji) oraz indeksów wiąże się też z kwestią odróżnienia edytorstwa naukowego od popularnonaukowego. Źródła kartograficzne są bowiem często udostępniane, szczególnie w środowisku internetowym, bez dokonania właściwej krytyki, szczególnie określenia specyfikacji i implementacji zasad rekodowania źródła, np. w zakresie skanowania ${ }^{73}$. Brak dokumentacji tego procesu jest kluczowy, ponieważ skany są współcześnie podstawą określania precyzji matematycznej map (analiza zniekształceń). Wówczas możemy mieć do czynienia z tzw. propagacją błędów, a niedokładny skan będzie wpływał na dokładność mapy (czy raczej jej obrazu). Brak dokumentacji doskwiera wielu projektom, np. Mapy z Przeszłością (http://hgis.cartomatic.pl/; dostęp: 31.12.2019) pozbawione są komentarza dotyczącego sposobu kalibracji map, a w tomie Atlasu Historycznego Miast Polskich (Świdnica) brak informacji o tym, że jedna z plansz przedstawia niezrealizowany projekt urbanistyczny ${ }^{74}$. Popularnonaukowy aspekt edytorstwa map ma jednak też pozytywną stronę, ponieważ może sprzyjać rozwojowi tzw. citizen science oraz crowdsourcingu, ze względu na atrakcyjność mapy jako formy prezentacji, o czym świadczą projekty związane z ich kalibracją ${ }^{75}$ i odczytem treści ${ }^{76}$.

71 P. Sahle, What is a Scholarly Digital Edition?, s. 19-41.

72 M. Słoń, Pryncypia edytorstwa, s. 160.

${ }^{73}$ P. Sahle, What is a Scholarly Digital Edition?, s. 24.

${ }^{74}$ M. Słoń, rec.: Świdnica, red. Rafat Eysymontt i Mateusz Goliński, Wydawnictwo Uniwersytetu Wrocławskiego, Atlas historyczny miast polskich, red. Roman Czaja, t. 4: Ślask, red. Marta Młynarska-Kaletynowa, z. 5, Wrocław 2008, ss. 60, il. 61, St. Źródł., 47, 2009, s. 218-220.

${ }^{75}$ Ch. Fleet, K.C. Kowal, P. Přidal, Georeferencer. Crowdsourced Georeferencing for Map Library Collections, „D-Lib Magazine", 18, 2012, nr 11/12, <http://www.dlib.org/dlib/november12/fleet/11fleet.html> [dostęp: 16.09.2020].

76 D. Lafreniere, L. Weidner, D. Trepal, S.F. Scarlett, J. Arnold, R. Pastel, R. Williams, Public Participatory Historical GIS, „Historical Methods. A Journal of Quantitative and Interdisciplinary History”, 52, 2019, nr 3, s. 132-149. 


\section{Rola narzędzi cyfrowych $w$ edytorstwie map}

Narzędzia cyfrowe umożliwiają opracowanie pełnej reprezentacji mapy i jej treści oraz dokumentację tego procesu. Mapa może zostać skalibrowana, tj. dopasowana do współczesnego układu współrzędnych i nałożona na inne, np. współczesne mapy; jej obraz może być uczytelniony, a grafika zrekonstruowana; poszczególne arkusze mogą być połączone w jedną, spójną całość. Treść mapy oddana jest w formie bazy danych, która pozwala na wyszukiwanie obiektów według różnych kryteriów (nazwa, typ, położenie) oraz wykonywanie analiz przestrzennych w programach GIS. Dzięki systemowi identyfikatorów obiekty z mapy, np. miejscowości, mogą być powiązane z obiektami z innych baz danych, dzięki czemu można analizować zmiany sieci osadniczej w ujęciu diachronicznym. Wszystkie komponenty edycji powinny być możliwe do pobrania, aby zapewnić użytkownikom możliwość wykorzystywania danych, prowadzenia własnych analiz i uzupełniania edycji, co wpisuje się w koncepcję „edycji bez końca"77. Osiągnięcie takich funkcjonalności jest niemożliwe bez narzędzi cyfrowych i realizacji paradygmatu cyfrowego.

\section{Edycja mapy a kartografia historyczna}

W kontekście cyfrowego edytorstwa źródeł kartograficznych istotną kwestią jest zakres ingerencji edytorskich, które odróżniają edycję treści mapy dawnej (wektoryzacja w bazie danych) od opracowania mapy historycznej. Dla S.E. Wiberleya edycja mapy to jej przerysowanie, uwspółcześnienie symbolizacji i korygowanie geometriii ${ }^{78}$. Przygotowując edycję mapy Gaula/Raczyńskiego, autor zdecydował się uzupełnić jej braki na podstawie mapy Gilly’ego. Można to uzasadnić dwojako: po pierwsze mapa Gilly'ego była jej głównym źródłem danych, a po drugie uzupełnieniom podlegały jedynie te elementy rysunku, które były widoczne na mapie Gaula/Raczyńskiego, ale z różnych przyczyn nieczytelne, np. zasięg zabudowy miejscowości pozbawiony nazwy (por. ryc. 1-B). Według autora, uzupełnianie informacji, których ślady są na mapie podlegającej edycji, jest jeszcze jej edycją (mapą źródłową), natomiast dodawanie do niej nowych obiektów na podstawie innych map - opracowywaniem mapy historycznej (mapy wynikowej). Innymi słowy: dodanie nazwy do miejscowości, której zabudowa została wyrysowana, to uzupełnienie informacji, a dodanie zupełnie nowej miejscowości to dodanie informacji i początek opracowywania mapy historycznej. Mapą historyczną w kontekście edytorskim będzie już jednak łączenie treści różnych źródeł kartograficznych w ramach jednej aplikacji typu web GIS.

\section{Stabilność i utrzymanie cyfrowych projektów}

$\mathrm{Na}$ zakończenie warto zastanowić się jeszcze nad kwestią utrzymania cyfrowych projektów. Ich trwałość staje się kluczowym zagadnieniem, przy czym należy odróżnić dwie warstwy: informacyjną i prezentacyjną. Warstwa informacyjna, czyli dane - o ile udostępniane są w otwartych i powszechnie wspieranych formatach ${ }^{79}$ - powinny być obsługiwane przez kolejne lata ${ }^{80}$. Warstwa wizualizacyjna (prezentacyjna) powinna natomiast co jakiś czas być unowocześniana do technologii wykorzystywanej w danym czasie ${ }^{81}$. Najważniejsze jest jednak wsparcie instytucjonalne: serwery, obsługa danych, stabilne identyfikatory, metadane, słowa kluczowe, co zapewni danym wyszukiwalność, dostępność, interoperacyjność i możliwość ponownego użycia ${ }^{82}$. Na koniec wypada jeszcze zauważyć, że pobieranie danych może zapewnić dużą liczbę rozproszonych kopii, a intensywnie wykorzystywana w dalszych pracach edycja będzie dzięki nim częściowo „archiwizowana” w nowszych technologiach, o dłuższej perspektywie przetrwania.

\footnotetext{
77 M. Słoń, Sine initio et sine fine, s. 131-142.

78 S.E. Wiberley, Editing Maps, s. 499-510.

79 W przypadku danych przestrzennych np. ESRI Shapefile, GeoJSON, CSV.

${ }^{80}$ R. Roselli Del Turco, The Battle We Forgot to Fight. Should We Make a Case for Digital Editions?, w: Digital Scholarly Editing, s. 234.

${ }^{81}$ Tamże.

${ }^{82} \mathrm{O}$ założeniach FAIR (findable, accessible, interoperable i reusable) więcej w: M.D. Wilkinson, M. Dumontier i in., The FAIR Guiding Principles, s. 1-9.
} 


\section{Digital editions of the old maps: prospects and limitations on the example of the Gaul/Raczyński map (1807-1812)}

Summary: In the article, digital editions of cartographic sources are presented, both in terms of their theory and application. Although rules and foundations for the editing of written sources have already been well established in historical scholarship and date back to the $19^{\text {th }}$ century, maps and other cartographic sources have been somewhat overlooked and treated superficially. The author briefly describes how cartographic sources editing is characterised: there is no consistent definition of the methods and scope of editorial works so far. Thus, a definition is proposed here stating that a map edition is "the critical and documented representation of the map and its content". Based on the Gaul/Raczyński topographic map (ca 1: 125,000, 1807-1812), the author presents foundations for the so-called 'model edition' which includes: scanned map sheets, mosaicked map sheets, map with reconstructed symbology, georeferenced map, a spatial database of map's content, web application, downloadable edition data as well as documentation. Finally, some key issues are addressed, such as: relations between editing cartographic and written sources (previously established rules in textual criticism can also be applied to maps), differences between scientific and popular map editions (lack of documentation is the main difference), the role of digital tools in editing (they not only provide more functionality, but also document the editorial process), differences and dependencies between map editing, cartography and historical map (historical map elaboration starts where new content, beyond the edited map, is added to the edition), and - finally - problems of sustainability of digital projects (institutional support and the usage of FAIR principles).

Nota o autorze: Tomasz Panecki, dr, adiunkt w Zakładzie Atlasu Historycznego Instytutu Historii im. Tadeusza Manteuffla Polskiej Akademii Nauk. Absolwent geografii i historii. Na Wydziale Geografii i Studiów Regionalnych Uniwersytetu Warszawskiego przygotował pracę doktorską pt. Koncepcja struktury bazy danych historycznych obiektów topograficznych. Zainteresowania badawcze to przede wszystkim kartografia historyczna, cyfrowe edycje dawnych map oraz sposoby historycznej reprezentacji rzeczywistości geograficznej w źródłach pisanych i kartograficznych.

Author: Tomasz Panecki, PhD, assistant professor at the Department of Historical Atlas of the Tadeusz Manteuffel Institute of History, Polish Academy of Sciences. Obtained MA degree in history and geography and defended his doctoral thesis at the Faculty of Geography and Regional Studies of the University of Warsaw (The concept of historical topographic objects' database). Interested particularly in historical cartography, digital editions of historical maps and cartographic representation of historical data.

Instytut Historii im. Tadeusza Manteuffla

Polska Akademia Nauk

ul. Rynek Starego Miasta 29/31

00-272 Warszawa

e-mail: tpanecki@uw.edu.pl

\section{Bibliografia}

Affek A., Kalibracja map historycznych z zastosowaniem GIS, w: Źródła kartograficzne w badaniach krajobrazu kulturowego, red. J. Plit, J. Nita, Prace Komisji Krajobrazu Kulturowego, t. 16, Sosnowiec 2012, s. 48-62

Bukowski W., Janeczek A., Mapa józefińska (1779-1783) w przededniu edycji, „Studia Geohistorica”, 1, 2013, s. $91-112$

Czaja R., Historical Atlas of Polish Towns - Between Source Edition and the Cartographic Presentation of Research on the History of Towns, „Studia Geohistorica”, 6, 2018, s. 80-89

Głażewski A., Modele rzeczywistości geograficznej a modele danych przestrzennych, „Polski Przegląd Kartograficzny", 38, 2006, nr 3, s. 217-225

Konias A., Kartografia topograficzna państwa i zaboru pruskiego od II połowy XVIII wieku do połowy XX wieku, Słupsk 2010

Lafreniere D., Rivet D., Rescaling the Past through Mosaic Historical Cartography, „Journal of Maps”, 6, 2010, nr 6, s. $417-422$ 
Mastronunzio M., Dai Prà E., Editing Historical Maps. Comparative Cartography Using Maps as Tools, „e-Perimetron”, 11, 2016, nr 4, s. 183-195

Medyńska-Gulij B., Żuchowski T.J., European Topography in Eighteenth-Century Manuscript Maps, Poznań 2018

Olszewicz B., Polska kartografia wojskowa, Warszawa 1921

Panecki T., Koncepcja struktury bazy danych historycznych obiektów topograficznych, Warszawa 2018, mps pracy doktorskiej, Wydział Geografii i Studiów Regionalnych UW

Perret J., Gribaudi M., Barthelemy M., Roads and Cities of $18^{\text {th }}$ Century France, „Scientific Data”, 2, 2015, $<$ https://www.nature.com/articles/sdata201548> [dostęp: 16.09.2020]

Polczynski M., Polczynski M., Beauplan's Ukraine. Open Access Georeferenced Databases for Studies of Early Modern History of Central and Eastern Europe, „Miscellanea Geographica”, 23, 2019, nr 3, s. 185-193

Sahle P., What is a Scholarly Digital Edition?, w: Digital Scholarly Editing. Theories and Practices, red. M.J. Driscoll, E. Pierazzo, Cambridge 2016, s. 19-41

Schloen D., Schloen S., Beyond Gutenberg. Transcending the Document Paradigm in Digital Humanities, „Digital Humanities Quarterly", 8, 2014, nr 4, <http:/www.digitalhumanities.org/dhq/vol/8/4/000196/000196.html> [dostęp: 20.04.2020]

Skelton R.A., Maps. A Historical Survey of Their Study and Collecting, Chicago 1972

Słoń M., Pryncypia edytorstwa źródeł historycznych w dobie rewolucji cyfrowej, St. Źródł., 53, 2015, s. 155-161

Sowiński J., Między oryginałem, kopia a falsyfikatem. Polskie edycje faksymilowe, Kraków 2009

Tandecki J., Kopiński K., Edytorstwo źródel historycznych, Warszawa 2014

Wiberley S.E., Editing Maps. A Method for Historical Cartography, „Journal of Interdisciplinary History”, 10 , 1980, nr 3, s. 499-510

Żyszkowska W., Mapa Departamentu Poznańskiego Edwarda Raczyńskiego jako źródło w badaniach stanu i zmian środowiska Wielkopolski, „Biblioteka Polskiego Przeglądu Kartograficznego”, 3, 2012, s. 36-44 